\title{
Photocatalytic degradation of sulfamethazine by graphitic carbon nitride-modified zinc molybdate: Effects of synthesis method on performance, degradation kinetics, and mechanism
}

\author{
Jing Zhang a, Xuhui Mao a,*, Wei Xiao a, Yanfeng Zhuang b,\# \\ a School of Resources and Environmental Science, Hubei International Scientific and Technological Cooperation Base of Sustainable Resource and Energy, \\ Wuhan University, Wuhan 430079, Hubei, China \\ b School of Civil Engineering, Wuhan University, Wuhan 430072, Hubei, China
}

\section{A R T I C L E I N F O}

\section{Article history:}

Received 11 September 2017

Accepted 19 October 2017

Published 5 December 2017

Keywords:

Zinc molybdate

Graphitic carbon nitride

Photocatalysis

Sulfamethazine

Water treatment

\begin{abstract}
A B S T R A C T
In the present study, zinc molybdate $\left(\beta-\mathrm{ZnMoO}_{4}\right)$ and graphitic carbon nitride $\left(\mathrm{g}-\mathrm{C}_{3} \mathrm{~N}_{4}\right)$-modified $\beta-\mathrm{ZnMoO}_{4}\left(\beta-\mathrm{ZnMoO} \mathrm{O}_{4} / \mathrm{g}-\mathrm{C}_{3} \mathrm{~N}_{4}\right)$ were prepared to decontaminate aqueous solutions from the antibiotic sulfamethazine (SMZ). Our results revealed that the hydrothermal synthesis method greatly influenced the photocatalytic activity of the resultant catalysts. The pristine $\beta-\mathrm{ZnMoO}_{4}$ samples obtained under more intensive synthesis conditions $\left(24 \mathrm{~h}\right.$ at $\left.280^{\circ} \mathrm{C}\right)$ showed higher photocatalytic activity than that prepared for $12 \mathrm{~h}$ at $180^{\circ} \mathrm{C}$ (denoted $\beta-\mathrm{ZnMoO}_{4}-180$ ). In the case of in situ hydrothermal synthesis of $\beta-\mathrm{ZnMoO}_{4} / \mathrm{g}_{-} \mathrm{C}_{3} \mathrm{~N}_{4}$, a surface-modified sample was only obtained under the reaction conditions of $180{ }^{\circ} \mathrm{C}$ for $12 \mathrm{~h}$. Compared with the sheet-like $\beta$ - $\mathrm{ZnMoO}_{4}-180$ sample, the $\beta-\mathrm{ZnMoO}_{4}-180 / \mathrm{g}-\mathrm{C}_{3} \mathrm{~N}_{4}$ composite showed enhanced photocatalytic activity for the degradation of SMZ. By contrast, the hydrothermal reaction at $280{ }^{\circ} \mathrm{C}$ caused the gradual decomposition of g- $\mathrm{C}_{3} \mathrm{~N}_{4}$. It is believed that the structural incorporation of $\mathrm{g}^{-} \mathrm{C}_{3} \mathrm{~N}_{4}$ into $\beta-\mathrm{ZnMoO}_{4}$ at $280^{\circ} \mathrm{C}$ might disrupt the crystal growth, thereby deteriorating the performance of the composite catalysts formed at this temperature. For the composite catalysts prepared by the ultrasonic method, a remarkable increase in the degradation rate of SMZ was only observed at a high $\mathrm{g}-\mathrm{C}_{3} \mathrm{~N}_{4}$ content of $8 \mathrm{~mol} \%$. The photocatalytic degradation of $\mathrm{SMZ}$ by $\beta-\mathrm{ZnMoO}_{4}-180 / \mathrm{g}-\mathrm{C}_{3} \mathrm{~N}_{4}$ composite catalysts followed pseudo-first-order kinetics. Further study of the photocatalytic mechanism revealed that holes and superoxide radicals were the dominant oxidative species in the photodegradation process. The enhanced photocatalytic performance of the composites was attributed to the higher separation efficiency of the photogenerated electron-hole pairs at heterogeneous junctions. The degradation intermediates of SMZ were detected by liquid chromatography-mass spectrometry, from which plausible reaction pathways for the photodegradation of SMZ were proposed. Our results indicated that the synthesis method for $\mathrm{g}_{-} \mathrm{C}_{3} \mathrm{~N}_{4}$ composites should be carefully selected to achieve superior photocatalytic performance.
\end{abstract}

(C) 2017, Dalian Institute of Chemical Physics, Chinese Academy of Sciences. Published by Elsevier B.V. All rights reserved.

\footnotetext{
* Corresponding author. Tel: +86-27-68775799; E-mail: clab@whu.edu.cn

\# Corresponding author. Tel: +86-27-68775799; E-mail: zhuang0848@sina.com

This work was supported by the National Natural Science Foundation of China (51778505) and the grants from Hubei Province of China (Special Grant for Technological Innovation (2016ACA162), and the Natural Science Foundation, 2015CFA017).

DOI: 10.1016/S1872-2067(17)62935-8 | http://www.sciencedirect.com/science/journal/18722067 | Chin. J. Catal., Vol. 38, No. 12, December 2017
} 


\section{Introduction}

In the past several decades, the use of molybdates as functional materials has been attracting great attention because of their favorable properties and complex chemistry. A variety of molybdates have been synthesized for different purposes. For example, divalent transition metal molybdates $\mathrm{NiMoO}_{4}$ and $\mathrm{CoMoO}_{4}$ demonstrated excellent good rate capability and high specific capacitances when used as electrodes for electrochemical capacitors [1,2]. Meanwhile, divalent metal molybdates with the general formula $\mathrm{MMoO}_{4}(\mathrm{M}=\mathrm{Ca}, \mathrm{Mg}, \mathrm{Zn})$ are semiconductors that have drawn considerable interest because of their potential applications in luminescence, catalysis, capacitors, and scintillation detectors [3-5]. Among divalent metal molybdates, the synthesis and use of zinc molybdates are attractive because zinc cations are recognized as inorganic nodes' for the design of porous inorganic compounds and metal semiconductors [6]. Zinc molybdates possess complex structures and their general chemical formula can be expressed as $n \mathrm{ZnO} \cdot \mathrm{mMoO}_{3}(n=3,2$, or 1 and $m=2,3$, or 1$)$, in which the molybdenum cation has a valence of +6 or +4 . Compounds with different stoichiometric ratios, including $\mathrm{ZnMoO}_{4}, \mathrm{Zn}_{2} \mathrm{Mo}_{3} \mathrm{O}_{8}$, and $\mathrm{Zn}_{3} \mathrm{Mo}_{2} \mathrm{O}_{9}$, have also been reported [7]. In particular, $\mathrm{ZnMoO}_{4}$ crystals show similarities with Aurivillius-type compounds, and have different crystalline phases, such as $\alpha-\mathrm{ZnMoO}_{4}$ (JCPDS No. 35-0765), $\beta-\mathrm{ZnMoO}_{4}$ (JCPDS No. 25-1024), and $\mathrm{ZnMoO}_{4} \cdot 0.8 \mathrm{H}_{2} \mathrm{O}$ (JCPDS No.25-1025). Among the three phases, $\alpha-\mathrm{ZnMoO}_{4}$ has a triclinic structure and is characterized by the structural group $\left[\mathrm{ZnO}_{6} / \mathrm{MoO}_{4}\right]$ with tetrahedral $\mathrm{MoO}_{4}{ }^{2-}$ anions. The other two phases possess monoclinic structures described by distorted $\left[\mathrm{ZnO}_{6}\right] /\left[\mathrm{MoO}_{6}\right]$ groups with octahedral $\mathrm{MoO}_{6}{ }^{6-}$ anions [8]. These materials are semiconducting; triclinic $\alpha-\mathrm{ZnMoO}_{4}$ was reported to have a bandgap of $3.3 \mathrm{eV}$, while monoclinic $\beta-\mathrm{ZnMoO}_{4}$ was characterized with bandgaps of around 3.13-3.51 eV [9] and 2.74-2.85 eV [8]. To date, $\mathrm{ZnMoO}_{4}$ has been used to effectively treat methyl orange [10], Victoria blue R, and phenol [8] under visible or ultraviolet (UV) light.

China has the largest source of molybdenum in the world (>19.6 Mt) [11]. The vast majority of the molybdenum is used in the production of high-strength steels employed in bridges, power plants, and pipelines. An alternative value-added use of molybdenum is in decontamination materials. In the present study, $\quad \beta-\mathrm{ZnMoO}_{4}$ and graphitic carbon nitride (g- $\mathrm{C}_{3} \mathrm{~N}_{4}$ )-modified $\beta-\mathrm{ZnMoO}_{4}$ are synthesized to explore the feasibility of using these materials for the photocatalytic degradation of organic pollutants. We combine $\beta-\mathrm{ZnMoO}_{4}$ with g- $\mathrm{C}_{3} \mathrm{~N}_{4}$ because it is a low-cost light-active material that has been reported to enhance the photocatalytic performance of composites via a type II or Z-scheme mechanism [12]. Meanwhile, g- $\mathrm{C}_{3} \mathrm{~N}_{4}$ itself is a photocatalyst that is responsive to visible light. The introduction of $\mathrm{g}-\mathrm{C}_{3} \mathrm{~N}_{4}$ to $\beta-\mathrm{ZnMoO}_{4}$ may improve the photocatalytic performance of the resulting $\mathrm{ZnMoO}_{4} / \mathrm{g}-\mathrm{C}_{3} \mathrm{~N}_{4}$ composite in the visible light region via the formation of heterogeneous junctions. Multiple approaches to synthesize g- $\mathrm{C}_{3} \mathrm{~N}_{4}$ composites have been reported, including in situ hydrothermal treatment [13-16], ultrasonication [17-20], one-step heating
[21-28], and precipitation [29,30]. Han et al. [31] prepared g- $\mathrm{C}_{3} \mathrm{~N}_{4}$-hybridized $\mathrm{TiO}_{2}$ nanofibers by an electrospinning process combined with a heat-etching method. Liao and colleagues fabricated a graphene oxide/g- $\mathrm{C}_{3} \mathrm{~N}_{4}$ composite photocatalyst using a sonochemical approach [19]. Although various g- $\mathrm{C}_{3} \mathrm{~N}_{4}$-based composites have been prepared by the above-mentioned methods, few studies have investigated the effect of the synthesis method on the performance of the resulting materials.

Therefore, in the present study, we use different methods to synthesize composite catalysts, and explore the effect of synthesis method on the performance of catalysts in which $\beta-\mathrm{ZnMoO}_{4}$ and $\mathrm{g}-\mathrm{C}_{3} \mathrm{~N}_{4}$ serve as the host material and dopant material, respectively. Sulfamethazine (SMZ), as one of the most commonly used antibiotics, is selected as a model pollutant because of its presence in natural water streams and adverse effects on living beings $[32,33]$. The performance of the composite photocatalysts is tested by SMZ degradation experiments. The kinetics and degradation pathways of SMZ over the course of degradation are accordingly studied. We hope that this study will not only deepen our understanding of $\mathrm{ZnMoO}_{4}$-based photocatalysts, but also give clues to find simple and effective strategies to obtain high-performance composite photocatalysts.

\section{Experimental}

\subsection{Chemicals}

Analytical-grade chemicals including zinc nitrate hexahydrate, sodium molybdate dihydrate, $p$-benzoquinone (BQ), triethanolamine (TEOA), sodium azide $\left(\mathrm{NaN}_{3}\right), t$-butanol (TBA), formic acid, and ethanol, along with methanol (high-performance liquid chromatography (HPLC) grade) were all purchased from Shanghai Sinopharm Chemical Reagent Co., Ltd. Melamine (99\%) and SMZ (99\%) were purchased from Shanghai Aladdin Industrial Corporation. Ultrapure water was used throughout this work.

\subsection{Catalyst preparation}

$\beta-\mathrm{ZnMoO}_{4}$ powder was synthesized by hydrothermal reaction under various conditions [8]. For the $\beta-\mathrm{ZnMoO}_{4}$ powder obtained at $180{ }^{\circ} \mathrm{C}$ (denoted $\beta-\mathrm{ZnMoO}_{4}-180$ ), $\mathrm{Zn}(\mathrm{NO})_{3} \cdot 6 \mathrm{H}_{2} \mathrm{O}$ and $\mathrm{Na}_{2} \mathrm{MoO}_{4} \cdot 2 \mathrm{H}_{2} \mathrm{O}$ with a molar ratio of $1: 1$ were used as the starting materials, which were separately dissolved in ultrapure water and then mixed under constant stirring. The mixture was transferred to a Teflon-lined autoclave and heated at $180{ }^{\circ} \mathrm{C}$ for $12 \mathrm{~h}$. The crude powder was collected, washed with water and ethanol several times, and then dried at $60{ }^{\circ} \mathrm{C}$ for $12 \mathrm{~h}$ to give $\beta$-ZnMoO $4-180$. For the $\beta-\mathrm{ZnMoO}_{4}$ powder obtained at $280{ }^{\circ} \mathrm{C}\left(\beta-\mathrm{ZnMoO}_{4}-280\right)$, a 1:2 molar ratio of Mo to $\mathrm{Zn}$ was used and the hydrothermal conditions were $280{ }^{\circ} \mathrm{C}$ for 24 h. We obtained $g-\mathrm{C}_{3} \mathrm{~N}_{4}$ by a thermal polycondensation process in a tube furnace [34]. The precursor melamine powder was transferred into a ceramic crucible and heated at a rate of 5 ${ }^{\circ} \mathrm{C} / \mathrm{min}$ to $300{ }^{\circ} \mathrm{C}$ for $2 \mathrm{~h}$; further deammoniation treatment 
was subsequently performed at $520^{\circ} \mathrm{C}$ for $2 \mathrm{~h}$.

The g- $\mathrm{C}_{3} \mathrm{~N}_{4}$-modified $\mathrm{ZnMoO}_{4}\left(\beta-\mathrm{ZnMoO}_{4} / \mathrm{g}-\mathrm{C}_{3} \mathrm{~N}_{4}-\mathrm{X} \%\right)$ samples were prepared by in situ hydrothermal synthesis. In this case, g- $\mathrm{C}_{3} \mathrm{~N}_{4}$ powder was added to the $\mathrm{Na}_{2} \mathrm{MoO}_{4}$ solution with a g- $\mathrm{C}_{3} \mathrm{~N}_{4}$ /Mo molar ratio of $1: 100,2: 100,3: 100,4: 100,5: 100$, or $8: 100$, and then the subsequent steps were the same as those used to synthesize $\beta-\mathrm{ZnMoO}_{4}$. In addition, $\beta-\mathrm{ZnMoO}_{4} / \mathrm{g}-\mathrm{C}_{3} \mathrm{~N}_{4}-\mathrm{X} \%$-U samples were also prepared by an ultrasonication method. An appropriate amount of $\mathrm{g}-\mathrm{C}_{3} \mathrm{~N}_{4}$ was completely dispersed in methanol assisted by ultrasonication. The as-prepared $\beta$ - $\mathrm{ZnMoO}_{4}$ powder was subsequently added and the mixture was stirred in a fume hood for $24 \mathrm{~h}$. The resulting powder was collected by centrifugation and then dried at $60^{\circ} \mathrm{C}$ for $12 \mathrm{~h}$.

\subsection{Photocatalytic degradation of SMZ}

The photocatalytic experiments were carried out under the irradiation of an 18-W light-emitting diode (LED). The central wavelength of the LED was $380 \mathrm{~nm}$, and it was placed at the bottom of a double-jacketed glass reactor. A given amount of catalyst (100 mg) was added to SMZ aqueous solution $(200 \mathrm{~mL}$, $2 \mathrm{mg} / \mathrm{L}$ ), and the mixture was mechanically stirred at $25^{\circ} \mathrm{C}$. Prior to irradiation, the mixture was constantly stirred under dark conditions for $30 \mathrm{~min}$ to ensure the adsorption equilibrium was reached. At specific time intervals, $2 \mathrm{~mL}$ aliquots were withdrawn. To remove the particles, each sample was filtered through a $0.45 \mu \mathrm{m}$ filter. To investigate the photodegradation mechanism, inhibition tests were carried out using different radical scavengers. BQ (0.2 mmol/L), TBA ( $0.2 \mathrm{~mol} / \mathrm{L}), \mathrm{NaN}_{3}$ $(0.012 \mathrm{~mol} / \mathrm{L})$, and TEOA ( $0.1 \mathrm{~mol} / \mathrm{L})$ were used as scavengers for superoxide radicals $\left(\bullet_{2}^{-}\right)$, hydroxyl radicals $(\bullet \mathrm{OH})$, singlet oxygen $\left({ }^{1} \mathrm{O}_{2}\right)$, and holes $\left(\mathrm{h}^{+}\right)$, respectively [22].

\subsection{Characterization and analytical methods}

Phase identification of samples was conducted by X-ray diffraction (XRD; Shimadzu X-ray 6000). The morphologies of samples were obtained by field-emission scanning electron microscope (FE-SEM; Zeiss SIGMA) and transmission electron microscopy (TEM; JEOL JEM-2010). Fourier transform infrared (FTIR) spectra were acquired by a Nicolet Avatar 360 spectrometer with $\mathrm{KBr}$ pellets in the $4000-400 \mathrm{~cm}^{-1}$ region. Specific surface areas were determined with the Brunauer-Emmett-Teller (BET) equation using an adsorption apparatus (Micromeritics ASAP2460, USA). X-ray photoelectron spectroscopy (XPS) was performed on a Thermo Scientific Escalab 250Xi spectrometer. The granulometric distribution of each sample was determined by a particle size analyzer (Microtrac S3500). UV-vis diffuse reflection spectroscopy (DRS) was performed on a Shimadzu UV-2550 spectrophotometer using $\mathrm{BaSO}_{4}$ as the reference. The concentration of ammonia nitrogen $\left(\mathrm{NH}_{4}{ }^{+}-\mathrm{N}\right)$ in each sample was measured by Nessler's reagent spectrophotometry. The Mott-Schottky analysis and electrochemical impedance spectroscopy (EIS) were performed with a three-electrode configuration in $0.1 \mathrm{~mol} / \mathrm{L} \mathrm{Na}_{2} \mathrm{SO}_{4}$ solutions, with a saturated calomel electrode (SCE) as the reference electrode. For these measurements, working electrodes were prepared by mixing and kneading the as-prepared catalysts with acetylene black (8:1) and binder (polytetrafluoroethylene, $35 \mathrm{wt} \%$ ) along with several drops of ethanol. The resulting slurry was rolled into film using a rolling machine. The film was cut into a square $(1 \times 1 \mathrm{~mm})$, which was then pressed onto a titanium mesh. Measurements were performed on an electrochemical workstation (CHI-660b, Shanghai Chenhua Co., Ltd, China).

The degradation products of SMZ were determined by HPLC (LC-15C, Shimadzu) using a system equipped with a UV absorbance detector. HPLC was conducted on a C18 reversed-phase column using a mobile phase of 30:70 methanol:water (containing $0.1 \%$ formic acid), with a flow rate of 1 $\mathrm{mL} / \mathrm{min}$, and detection wavelength of $270 \mathrm{~nm}$. The identification of intermediates was performed by liquid chromatography-mass spectrometry (LC-MS; Agilent 6460 triple quadrupole mass spectrometer) with an electrospray ionization source. A reversed-phase column (Agilent Eclipse Plus C18) was used with a flow rate of $0.3 \mathrm{~mL} / \mathrm{min}$, and the elution was accomplished with 20:80 methanol:water (containing 0.1\% formic acid). The total organic carbon (TOC) decay of solutions was determined on an Elementar Vario TOC analyzer. The inorganic ions in the solutions during photocatalytic degradation were measured by ion chromatography (Metrohm 930).

\section{Results and discussion}

\subsection{Materials characterization}

Fig. 1(a) presents the XRD patterns of $\mathrm{ZnMoO}_{4}$ crystals prepared under different conditions. All peaks were indexed to the crystalline structure of $\beta-\mathrm{ZnMoO}_{4}$ (JCPDS No. 25-1024) [8]. No diffraction peaks from other crystalline phases were detected, indicating that $\beta-\mathrm{ZnMoO}_{4}$ of good quality was successfully synthesized by the two hydrothermal procedures used. Fig. 1(b) shows the XRD patterns of the $\beta-\mathrm{ZnMoO}_{4} / \mathrm{g}-\mathrm{C}_{3} \mathrm{~N}_{4}$ composites prepared with different $\mathrm{g}-\mathrm{C}_{3} \mathrm{~N}_{4} /$ Mo molar ratios. The pure g- $\mathrm{C}_{3} \mathrm{~N}_{4}$ sample presented two obvious peaks consistent with g- $\mathrm{C}_{3} \mathrm{~N}_{4}$. The (002) peak was typical of interplanar stacking in conjugated aromatic systems, and the other one at $13^{\circ}(100)$ was associated with the in-plane structural packing motif of the tri-s-triazine units [35]. For the $\beta-\mathrm{ZnMoO}_{4}-180 / \mathrm{g}-\mathrm{C}_{3} \mathrm{~N}_{4}$ composites, the main peak at $27.5^{\circ}$ from $\mathrm{g}-\mathrm{C}_{3} \mathrm{~N}_{4}$ was observed, and the intensities of the peaks increased with the $\mathrm{g}-\mathrm{C}_{3} \mathrm{~N}_{4} /$ Mo ratio. Compared with that of the pristine $\mathrm{g}-\mathrm{C}_{3} \mathrm{~N}_{4}$, the main (002) peak of $g-\mathrm{C}_{3} \mathrm{~N}_{4}$ in the composite shifted slightly (by $0.3^{\circ}$ ), indicating the interlayer spacing decreased. This observation was also reported by other scholars [31]; a plausible reason for this phenomenon is that the interaction of $\mathrm{g}-\mathrm{C}_{3} \mathrm{~N}_{4}$ with $\mathrm{ZnMoO}_{4}$ influences its interplanar spacing.

SEM images of the samples revealed that the $\beta-\mathrm{ZnMoO}_{4}-180$ sample produced using a 1:1 Mo/Zn molar ratio had a sheet-like structure, and the sheets further assembled into flower-like shapes (Fig. 2(a)). Meanwhile, $\beta-\mathrm{ZnMoO}_{4}-280$ prepared with a 1:2 Mo/Zn molar ratio has an irregular shape with larger corners (Fig. 2(d)), which is similar to the morphology of 

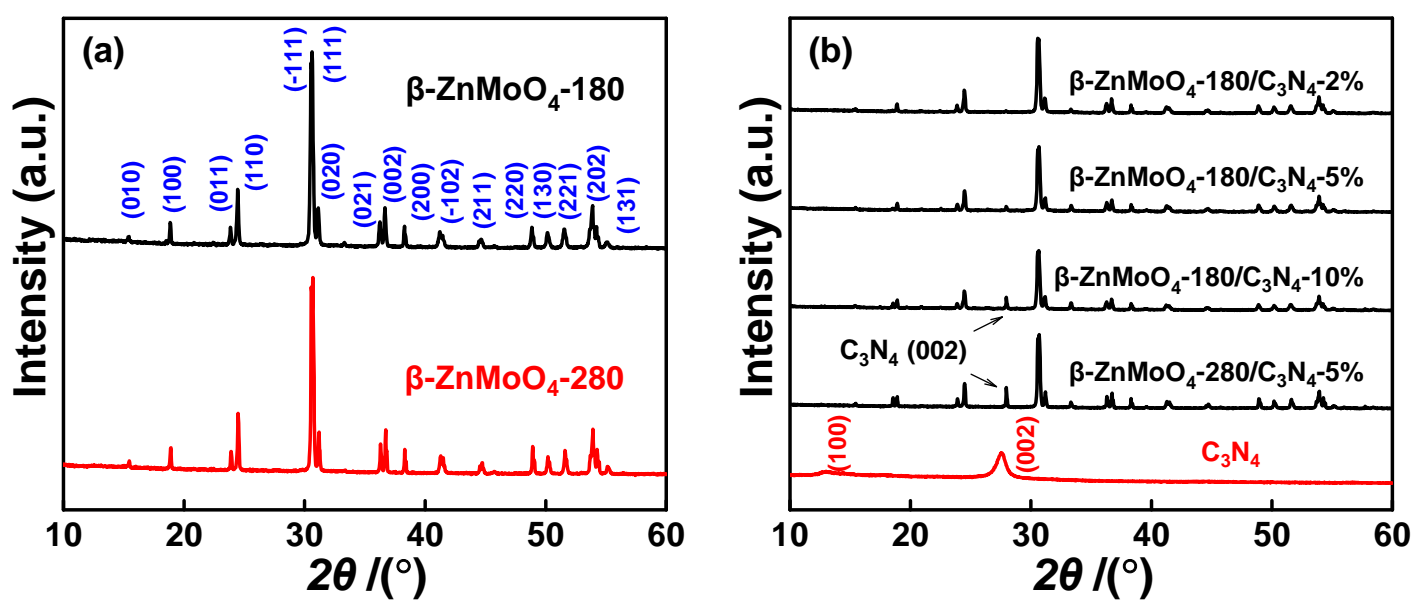

Fig. 1. XRD patterns of $\mathrm{ZnMoO}_{4}$ crystals prepared under different hydrothermal conditions (a) and g- $\mathrm{C}_{3} \mathrm{~N}_{4}$-modified $\mathrm{ZnMoO}_{4}$ prepared by in situ hydrothermal synthesis (b).

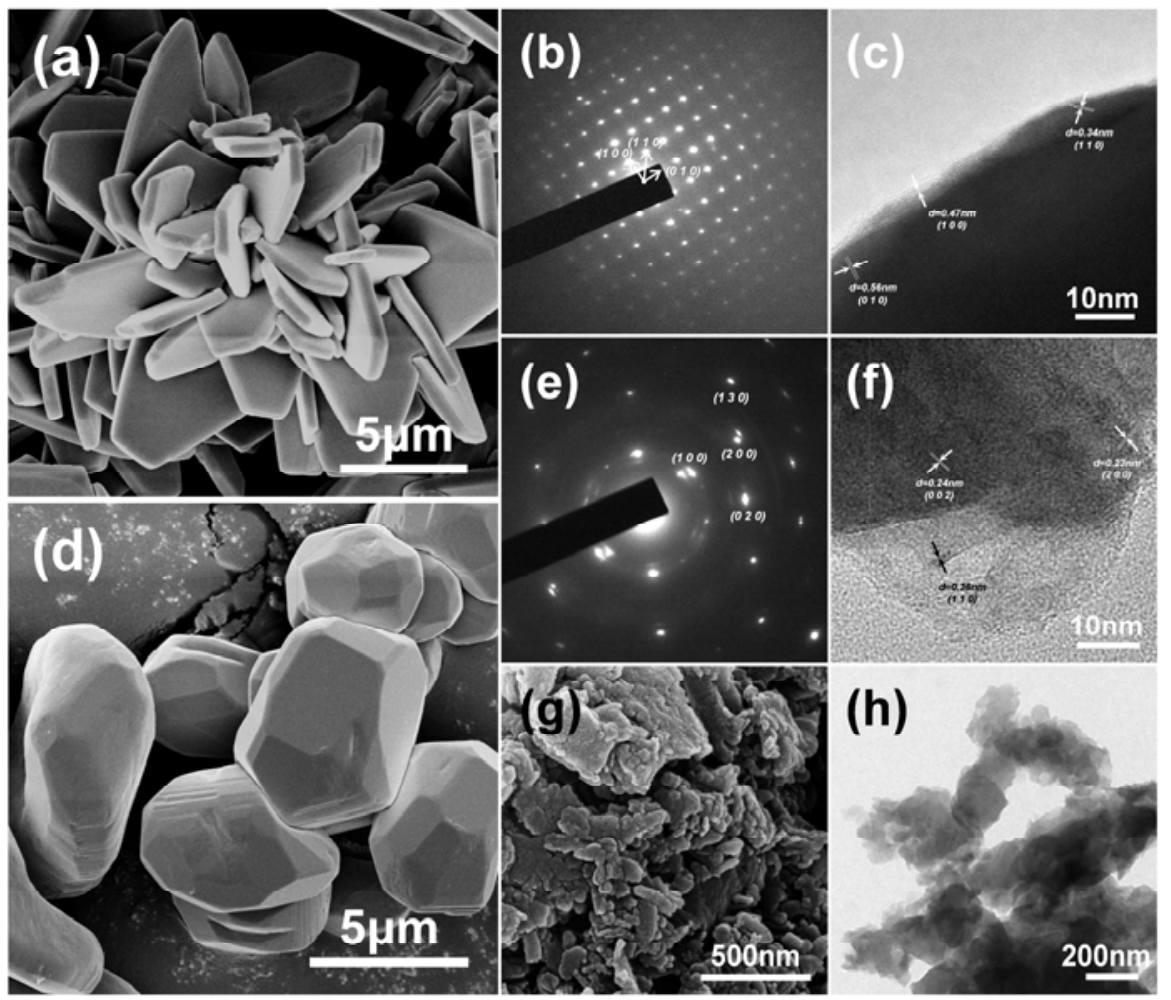

Fig. 2. SEM images, SAED patterns, and HRTEM images of $\beta-\mathrm{ZnMoO}_{4}-180(\mathrm{a}-\mathrm{c}), \beta-\mathrm{ZnMoO}_{4}-280(\mathrm{~d}-\mathrm{f})$, and g- $\mathrm{C}_{3} \mathrm{~N}_{4}(\mathrm{~g}, \mathrm{~h})$.

$\beta-\mathrm{ZnMoO}_{4}$ crystals reported by Jiang et al. [8]. The different initial contents of the starting materials and the varied hydrothermal conditions affected the rate and direction of crystal growth in the samples, leading to the formation of $\beta-\mathrm{ZnMoO}_{4}$ crystals with dissimilar morphologies. In addition, the surfaces of these microcrystals are very smooth, with low BET surface areas of $0.883 \mathrm{~m}^{2} / \mathrm{g}$ for $\beta-\mathrm{ZnMoO}_{4}-180$ and $0.491 \mathrm{~m}^{2} / \mathrm{g}$ for $\beta-\mathrm{ZnMoO}_{4}-280$. Fig. 2 (b) and (c) show a selected-area electron diffraction (SAED) pattern and high-resolution transmission electron microscopy (HRTEM) image of the $\beta-\mathrm{ZnMoO}_{4}-180$ sample, respectively. The lattice spacings in Fig. 2 (c) are 0.56, 0.47 , and $0.34 \mathrm{~nm}$, which correspond to the lattice spacings of the (010), (100), and (110) planes of the $\beta-\mathrm{ZnMoO}_{4}$ crystals, respectively. The corresponding SAED pattern demonstrates that the $\beta-\mathrm{ZnMoO}_{4}-180$ sample is monocrystalline. The SAED pattern of $\beta-\mathrm{ZnMoO}_{4}-280$ (Fig. 2(e)) indicates this sample has a polycrystalline nature, and its HRTEM image (Fig. 2(f)) has lattice spacings of $0.36,0.24$, and $0.23 \mathrm{~nm}$, corresponding to the lattice spacings of the (110), (002), and (200) planes, respectively. These results are in good accordance with those of the XRD pattern in Fig. 1(a). Fig. 2(g) and (h) show the morphology of the g- $\mathrm{C}_{3} \mathrm{~N}_{4}$ prepared in this study. The pristine g- $\mathrm{C}_{3} \mathrm{~N}_{4}$ existed in the form of small lumps, and its lamellar structure can be observed. This kind of structure makes g- $\mathrm{C}_{3} \mathrm{~N}_{4}$ easy to split into smaller blocks during ultrasonication.

Fig. 3 illustrates the morphologies of $\mathrm{g}-\mathrm{C}_{3} \mathrm{~N}_{4}$-modified 


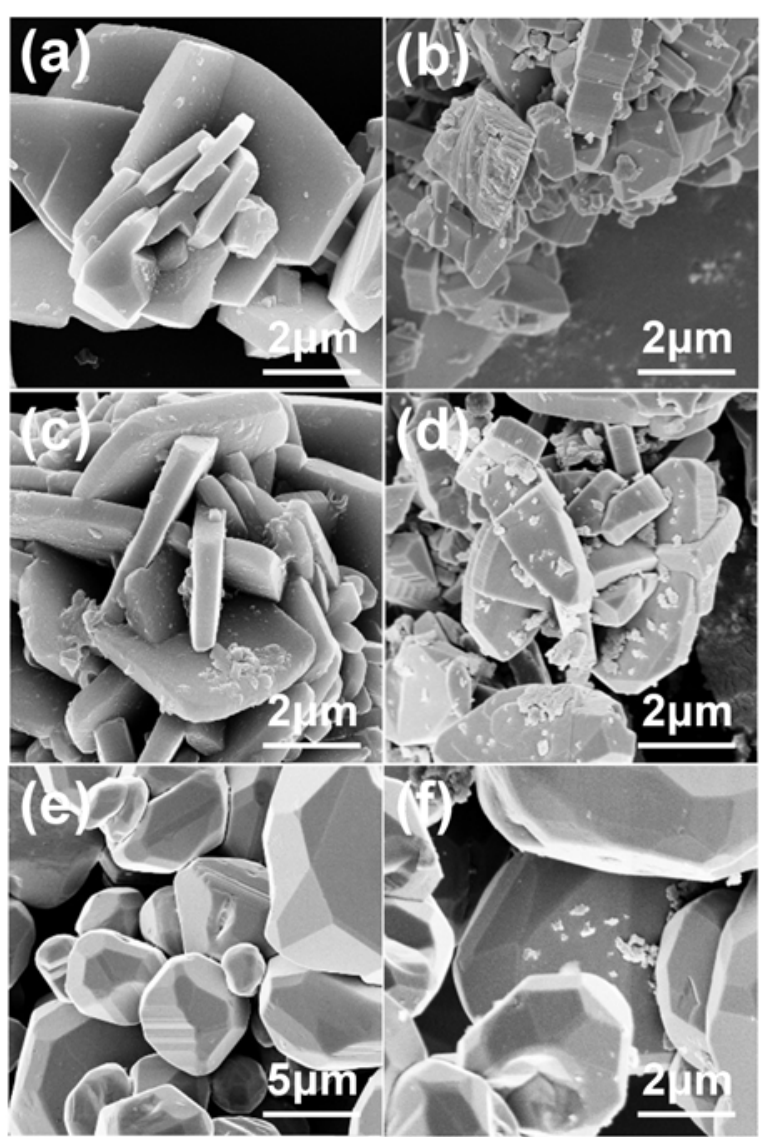

Fig. 3. SEM images of $\beta-\mathrm{ZnMoO}_{4}-180 / \mathrm{g}-\mathrm{C}_{3} \mathrm{~N}_{4}-2 \% \quad$ (a), $\beta-\mathrm{ZnMoO}_{4}-180 / \mathrm{g}-\mathrm{C}_{3} \mathrm{~N}_{4}-2 \%$-U $\quad$ (b), $\beta-\mathrm{ZnMoO}_{4}-180 / \mathrm{g}-\mathrm{C}_{3} \mathrm{~N}_{4}-5 \% \quad$ (c), $\beta-\mathrm{ZnMoO}_{4}-180 / \mathrm{g}-\mathrm{C}_{3} \mathrm{~N}_{4}-5 \%-\mathrm{U}$ (d), $\beta-\mathrm{ZnMoO}_{4}-280 / \mathrm{g}-\mathrm{C}_{3} \mathrm{~N}_{4}-2 \%$ (e) and $\beta-\mathrm{ZnMoO}_{4}-280 / \mathrm{g}-\mathrm{C}_{3} \mathrm{~N}_{4}-2 \%-\mathrm{U}$ (f).

$\beta-\mathrm{ZnMoO}_{4}$ prepared with different methods. For the samples prepared by the in situ hydrothermal method (Fig. 3(a), (c), and $(\mathrm{e})), \mathrm{g}-\mathrm{C}_{3} \mathrm{~N}_{4}$ particles were successfully loaded onto the surface of $\beta-\mathrm{ZnMoO}_{4}-180$, whereas no $\mathrm{g}-\mathrm{C}_{3} \mathrm{~N}_{4}$ particles were observed for the $\beta-\mathrm{ZnMoO}_{4}-280 / \mathrm{g}-\mathrm{C}_{3} \mathrm{~N}_{4}$ sample. The FTIR spectra (see Fig. S1 in Supporting Information (SI)) of the $\beta-\mathrm{ZnMoO}_{4}-280 / \mathrm{g}-\mathrm{C}_{3} \mathrm{~N}_{4}$ samples also suggested that no $\mathrm{g}-\mathrm{C}_{3} \mathrm{~N}_{4}$ could be detected on the surface of the $\beta-\mathrm{ZnMoO}_{4}-280$ crystals. This result is contradictory to the results of XRD in Fig. 1(b), in which the $\beta-\mathrm{ZnMoO}_{4}-280 / \mathrm{g}-\mathrm{C}_{3} \mathrm{~N}_{4}$ sample showed the characteristic peak of $\mathrm{g}-\mathrm{C}_{3} \mathrm{~N}_{4}$ at $27.5^{\circ}$. This observation suggests that the detected $\mathrm{g}-\mathrm{C}_{3} \mathrm{~N}_{4}$ might be incorporated into the structure of the composite, rather than modifying its surface. For the composites prepared by the ultrasonic method (Fig. 3(b), (d), and (f)), g- $\mathrm{C}_{3} \mathrm{~N}_{4}$ particles were observed on the surface of the $\beta-\mathrm{ZnMoO}_{4}$ crystals, and the loading of $\mathrm{g}-\mathrm{C}_{3} \mathrm{~N}_{4}$ particles increased with the $\mathrm{g}-\mathrm{C}_{3} \mathrm{~N}_{4} /$ Mo ratio. This experimental result suggests that the $\mathrm{g}-\mathrm{C}_{3} \mathrm{~N}_{4}$ particles can attach to the surface of $\beta-\mathrm{ZnMoO}_{4}$ crystals through the ultrasonic method. Therefore, extra experiments were carried out to examine why g- $\mathrm{C}_{3} \mathrm{~N}_{4}$ was not observed on the $\beta-\mathrm{ZnMoO}_{4}-280 / \mathrm{g}-\mathrm{C}_{3} \mathrm{~N}_{4}$ sample. Fig. S2 in the SI shows the concentrations of $\mathrm{NH}_{4}{ }^{+}-\mathrm{N}$ in the solutions after the hydrothermal treatment of $\mathrm{g}-\mathrm{C}_{3} \mathrm{~N}_{4}$ suspension for different periods. The inset in Fig. S2 reveals that suspended g- $\mathrm{C}_{3} \mathrm{~N}_{4}$ par- ticles still existed in the solution after treatment at $280{ }^{\circ} \mathrm{C}$ for $0.5 \mathrm{~h}$, and the solution become clear after treatment for $1 \mathrm{~h}$. Meanwhile, the $\mathrm{NH}_{4}{ }^{+}-\mathrm{N}$ concentration in the solutions increased, indicating some of the nitrogen in $\mathrm{g}-\mathrm{C}_{3} \mathrm{~N}_{4}$ was converted into dissolved $\mathrm{NH}_{4}{ }^{+}-\mathrm{N}$. The inset proves that during hydrothermal treatment at $280{ }^{\circ} \mathrm{C}$, the decomposition of $\mathrm{g}-\mathrm{C}_{3} \mathrm{~N}_{4}$ particles progressed. Some of the particles might be incorporated into $\beta-\mathrm{ZnMoO}_{4}$ crystals in the early stage of the hydrothermal process, while the rest of the $\mathrm{g}-\mathrm{C}_{3} \mathrm{~N}_{4}$ particles eventually decomposed, preventing the existence of surface-attached g- $\mathrm{C}_{3} \mathrm{~N}_{4}$ particles. This may explain why the characteristic diffraction peak of $\mathrm{g}-\mathrm{C}_{3} \mathrm{~N}_{4}$ was observed in the XRD pattern of the $\beta-\mathrm{ZnMoO}_{4}-280 / \mathrm{g}-\mathrm{C}_{3} \mathrm{~N}_{4}$ sample (Fig. $1(\mathrm{~b})$ ), but g- $\mathrm{C}_{3} \mathrm{~N}_{4}$ particles were not observed on the surface of the samples in the SEM images (Fig. 3(e)).

XPS analysis was used to investigate the chemical composition of the as-prepared $\beta-\mathrm{ZnMoO}_{4}$ and $\beta-\mathrm{ZnMoO}_{4} / \mathrm{g}-\mathrm{C}_{3} \mathrm{~N}_{4}$ composites. As shown in Fig. 4, the spin-orbit splitting of the Mo $3 d$ level gave rise to $3 d_{5 / 2}$ and $3 d_{3 / 2}$ levels with an energy separation of $3.2 \mathrm{eV}$, and the binding energies of 232.6 and $235.8 \mathrm{eV}$ corresponded to Mo $3 d_{5 / 2}$ and Mo $3 d_{3 / 2}$, respectively. The Mo $3 d_{5 / 2}$ peak revealed that Mo possessed a hexavalent oxidation state and the $\mathrm{Zn} 2 p_{3 / 2}$ peak at $1021.3 \mathrm{eV}$ revealed $\mathrm{Zn}$ had a divalent oxidation state [36]. The characteristic binding energy of $530.1 \mathrm{eV}$ for $01 \mathrm{~s}$ revealed 0 was present as a metal oxide. Regarding the g- $\mathrm{C}_{3} \mathrm{~N}_{4}$-modified $\beta-\mathrm{ZnMoO}_{4}$ prepared by the in situ hydrothermal synthesis method, there was no evident difference between the binding energies of $\mathrm{Zn}$, Mo, and $\mathrm{O}$ with or without g- $\mathrm{C}_{3} \mathrm{~N}_{4}$. In Fig. 4(c) and (d), the small deviation of Mo $3 d$ and $01 s$ may be caused by the different experimental conditions. Jiang et al. [8] reported a similar observation in their XPS analysis of different $\beta-\mathrm{ZnMoO}_{4}$ samples.

The particle size distribution curves of $\beta-\mathrm{ZnMoO}_{4}$ with different morphologies are shown in Fig. 5. Based on the distribution curves, the $\beta-\mathrm{ZnMoO}_{4}$ samples prepared under different hydrothermal reaction conditions with flower-like and irregular shapes possessed very similar average particle sizes $\left(D_{50}\right)$ of 15.02 and $17.80 \mu \mathrm{m}$, respectively. Finer particles were found for the $\beta-\mathrm{ZnMoO}_{4}-280$ sample, as can also be observed in the SEM images (Fig. 2). The $\beta-\mathrm{ZnMoO}_{4}-180$ sample had a narrower size distribution than that of $\beta-\mathrm{ZnMoO}_{4}-280$ because of its more regular sheet-like structure.

\subsection{Removal of SMZ by photocatalytic degradation}

The adsorption and photodegradation of SMZ by pristine $\beta-\mathrm{ZnMoO}_{4}$ samples were studied. Fig. 6(a) reveals that the two kinds of $\beta-\mathrm{ZnMoO}_{4}$ show very weak capability to uptake SMZ in the dark. The small BET surface area of the $\beta-\mathrm{ZnMoO}_{4}$ particles explains their poor SMZ adsorption ability. Fig. 6(b) shows the photocatalytic activities of the $\beta-\mathrm{ZnMoO}_{4}$ and g- $\mathrm{C}_{3} \mathrm{~N}_{4}$ particles for SMZ degradation. After irradiation for $3 \mathrm{~h}$, the degradation efficiencies of the $\beta-\mathrm{ZnMoO}_{4}-180$ sample with flower-like morphology, $\beta-\mathrm{ZnMoO}_{4}-280$ crystals with irregular corners, and $\mathrm{g}-\mathrm{C}_{3} \mathrm{~N}_{4}$ were $71 \%, 93 \%$, and $100 \%$, respectively. With increasing reaction temperature and time, the crystallinity of $\beta-\mathrm{ZnMoO}_{4}$ increased and its defect content decreased, leading 

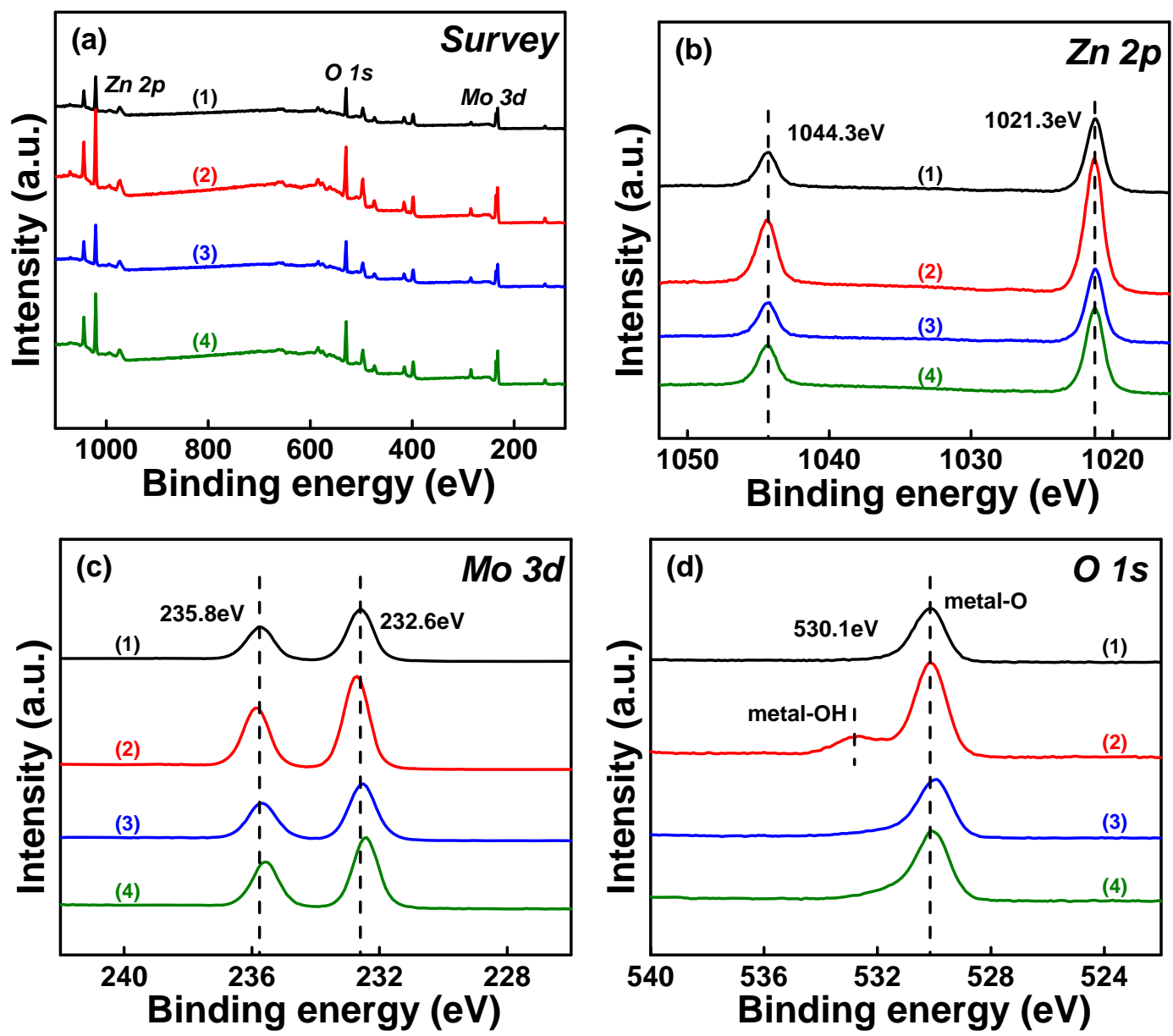

Fig. 4. XPS analysis of the $\beta-\mathrm{ZnMoO}_{4}$ and $\beta-\mathrm{ZnMoO}_{4} / \mathrm{g}-\mathrm{C}_{3} \mathrm{~N}_{4}-2 \%$ samples. $\beta-\mathrm{ZnMoO}_{4}-180$ (1); $\beta-\mathrm{ZnMoO}_{4}-280$ (2); $\beta-\mathrm{ZnMoO}-180 / \mathrm{g}-\mathrm{C}_{3} \mathrm{~N}_{4}-2 \%(3)$; and $\beta-\mathrm{ZnMoO}_{4}-280 / \mathrm{g}-\mathrm{C}_{3} \mathrm{~N}_{4}-2 \%$ (4).
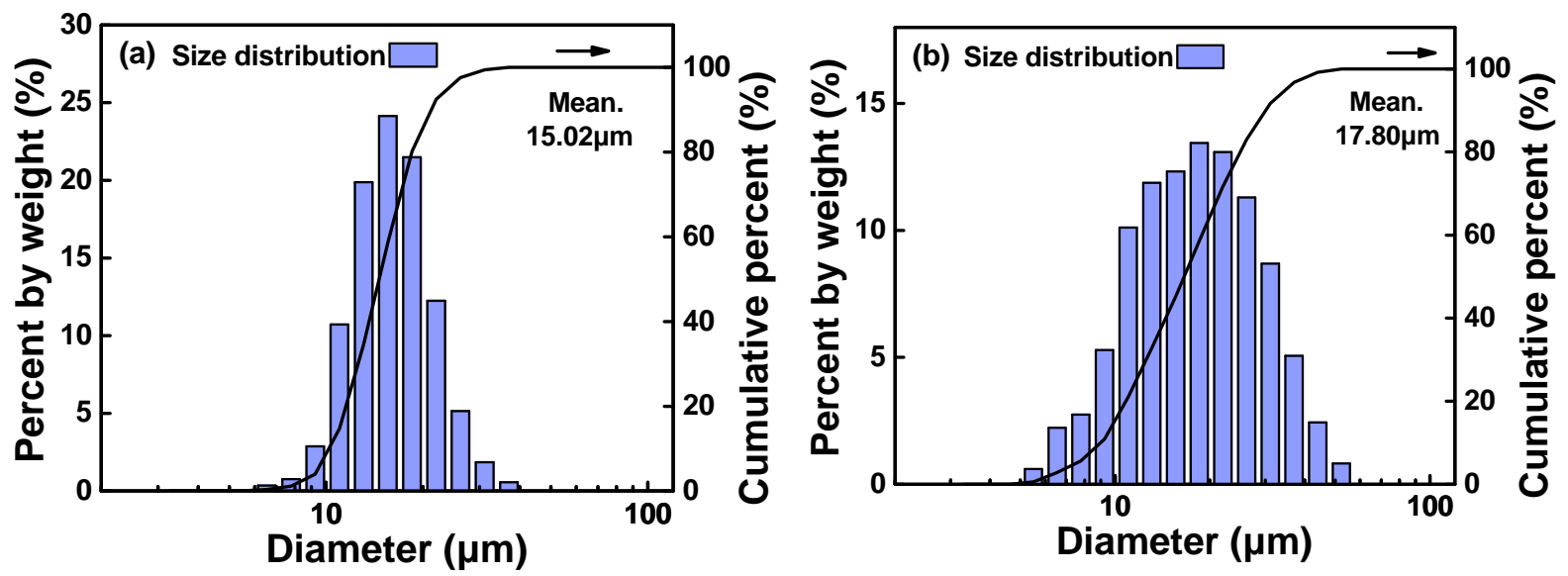

Fig. 5. Particle size distributions of the pristine $\beta-\mathrm{ZnMoO}_{4}$ samples. $\beta-\mathrm{ZnMoO}_{4}-180$ (a); $\beta-\mathrm{ZnMoO}_{4}-280$ (b).

to the enhanced photocatalytic activity of the $\beta-\mathrm{ZnMoO}_{4}-280$ sample over that of $\beta-\mathrm{ZnMoO}_{4}-180$ [8,37-39].

The photocatalytic activities of the $\beta-\mathrm{ZnMoO}_{4} / \mathrm{g}-\mathrm{C}_{3} \mathrm{~N}_{4}$ composites are presented in Fig. 6(c) and (d). The photocatalytic degradation of SMZ by the composites follows pseudo-first-order kinetics. In the case of g- $\mathrm{C}_{3} \mathrm{~N}_{4}$-modified
$\beta-\mathrm{ZnMoO}_{4}-180$ (Fig. 6(c)), the photodegradation experiments revealed that this composite showed higher photocatalytic activity than that of $\beta-\mathrm{ZnMoO}_{4}-180$. When the g- $\mathrm{C}_{3} \mathrm{~N}_{4} /$ Mo ratio was $3: 100$, the maximum photodegradation rate was achieved. Fig. 6(d) illustrates that the $\beta-\mathrm{ZnMoO}_{4}-280 / g-\mathrm{C}_{3} \mathrm{~N}_{4}$ composites showed lower photocatalytic activities than that of 

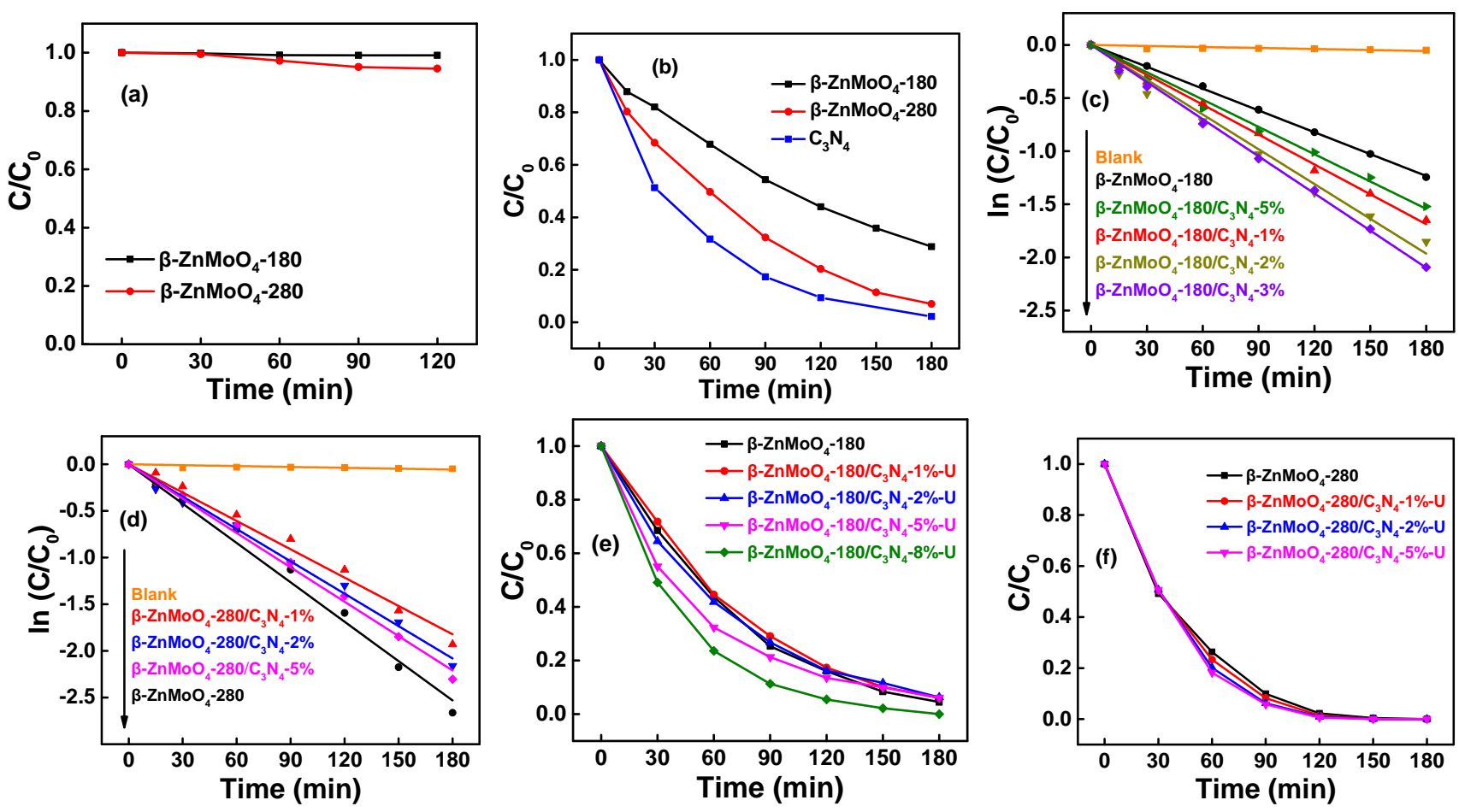

Fig. 6. Adsorption (a) and photocatalytic degradation (b) of SMZ by $\beta-\mathrm{ZnMoO}_{4}$. The photocatalytic degradation of $\mathrm{SMZ}$ by $\beta-\mathrm{ZnMoO}$ - $180 / \mathrm{g}-\mathrm{C}_{3} \mathrm{~N}_{4}$ (c), $\beta-\mathrm{ZnMoO}_{4}-280 / \mathrm{g}-\mathrm{C}_{3} \mathrm{~N}_{4}(\mathrm{~d}), \beta-\mathrm{ZnMoO}_{4}-180 / \mathrm{g}-\mathrm{C}_{3} \mathrm{~N}_{4}-\mathrm{U}$ (e), and $\beta-\mathrm{ZnMoO}_{4}-280 / \mathrm{g}-\mathrm{C}_{3} \mathrm{~N}_{4}-\mathrm{U}$ (f). For (e) and (f), the photocatalytic experiments were performed by adding $200 \mathrm{mg}$ of catalyst to $200 \mathrm{~mL}$ of SMZ solution.

$\beta-\mathrm{ZnMoO}_{4}-280$; namely, the introduction of $\mathrm{g}^{-} \mathrm{C}_{3} \mathrm{~N}_{4}$ lowered the performance of this catalyst. Fig. 6(e) and (f) show the photocatalytic activities of $\beta-\mathrm{ZnMoO}_{4}$ and g- $\mathrm{C}_{3} \mathrm{~N}_{4}$-modified $\beta-\mathrm{ZnMoO}_{4}$ photocatalysts prepared by the ultrasonic method. With increasing $\mathrm{g}-\mathrm{C}_{3} \mathrm{~N}_{4}$ content, the photodegradation abilities of the two kinds of $\beta-\mathrm{ZnMoO}_{4}$ improved slightly. For the $\beta-\mathrm{ZnMoO}_{4}-180 / \mathrm{g}-\mathrm{C}_{3} \mathrm{~N}_{4}-\mathrm{U}$ samples (Fig. 6(e)), considerably enhanced degradation of SMZ was only observed for the composite sample with $8 \% \mathrm{~g}-\mathrm{C}_{3} \mathrm{~N}_{4}$. For the $\beta-\mathrm{ZnMoO}_{4}-280$ samples (Fig. 6(f)), modification with $\mathrm{g}-\mathrm{C}_{3} \mathrm{~N}_{4}$ by the ultrasonic method only weakly influenced the photocatalytic degradation of SMZ. The above results reveal that all the surface-modified $\beta-\mathrm{ZnMoO}_{4} / \mathrm{g}-\mathrm{C}_{3} \mathrm{~N}_{4}$ samples were better than the pristine $\beta-\mathrm{ZnMoO}_{4}$ samples at $\mathrm{SMZ}$ photodegradation. In particular, the $\beta-\mathrm{ZnMoO}_{4}-180 / \mathrm{g}-\mathrm{C}_{3} \mathrm{~N}_{4}$ sample with $3 \% \mathrm{~g}-\mathrm{C}_{3} \mathrm{~N}_{4}$ prepared by the in situ hydrothermal method exhibited high photodegradation efficiency, indicating this synthesis method allowed good bonding between the $\beta-\mathrm{ZnMoO}_{4}$ and g- $\mathrm{C}_{3} \mathrm{~N}_{4}$ particles. Retardation of photoactivity following g- $\mathrm{C}_{3} \mathrm{~N}_{4}$ addition was only found for the $\beta-\mathrm{ZnMoO}_{4}-280 / \mathrm{g}-\mathrm{C}_{3} \mathrm{~N}_{4}$ sample prepared by the in-situ hydrothermal method. Different from the surface-attached g- $\mathrm{C}_{3} \mathrm{~N}_{4}$, the structural incorporation of $\mathrm{g}-\mathrm{C}_{3} \mathrm{~N}_{4}$ into $\beta-\mathrm{ZnMoO}_{4}-280$ may decrease its crystallinity, resulting in its poor photocatalytic activity.

The growth mechanism of the $\beta_{-2 n M o O}$ and $\beta-\mathrm{ZnMoO}_{4} / \mathrm{g}-\mathrm{C}_{3} \mathrm{~N}_{4}$ composites synthesized by the hydrothermal method are shown in Fig. 7. The growth of zinc molybdate crystals mainly involves the following stages $[8,40]$ : (a) nucleation of the first clusters or nuclei, (b) self-assembly of small crystallites, and (c) crystal growth. The electrostatic attraction between $\mathrm{Zn}^{2+}$ and $\mathrm{MoO}_{4}{ }^{2-}$ promotes the nucleation process that produces the initial $\beta-\mathrm{ZnMoO}_{4}$ precipitates or nuclei. The hydrothermal conditions increase the effective collision frequency of the nanoparticles in the suspension. At a reaction temperature of $180{ }^{\circ} \mathrm{C}$, the nanoparticles aggregate to form plate-like $\mathrm{\beta}_{-\mathrm{ZnMoO}} \mathrm{M}_{4}$ microcrystals. At $280{ }^{\circ} \mathrm{C}$, the intensified self-aggregation of particles compared with that at $180{ }^{\circ} \mathrm{C}$ resulted in the formation of $\beta-\mathrm{ZnMoO}_{4}$ microparticles with irregular shape. When using the in situ hydrothermal method to synthesize the $\mathrm{g}-\mathrm{C}_{3} \mathrm{~N}_{4}$-modified $\beta-\mathrm{ZnMoO}_{4}$ composites, temperature-dependent results were obtained because of the different

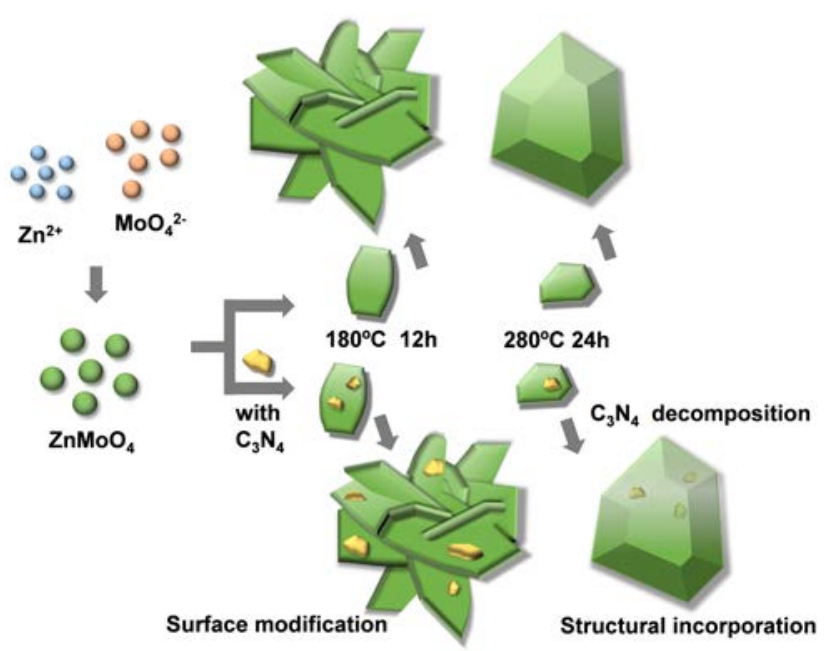

Fig. 7. Schematic illustration of the growth mechanism of $\beta-\mathrm{ZnMoO}_{4}$ and $\beta-\mathrm{ZnMoO}_{4} / \mathrm{g}-\mathrm{C}_{3} \mathrm{~N}_{4}$ composites prepared by the hydrothermal method. 
growth pathways of $\beta-\mathrm{ZnMoO}_{4}$ crystals at different temperatures. While $\mathrm{g}-\mathrm{C}_{3} \mathrm{~N}_{4}$ bound to the surface of flower-like $\beta-\mathrm{ZnMoO}_{4}-180$, it was included inside the $\beta-\mathrm{ZnMoO}_{4}-280$ crystals of the $\beta-\mathrm{ZnMoO} 4-280 / \mathrm{g}-\mathrm{C}_{3} \mathrm{~N}_{4}$ sample. The structural incorporation of $\mathrm{g}-\mathrm{C}_{3} \mathrm{~N}_{4}$ into the composite may lower the crystallinity of $\beta-\mathrm{ZnMoO}_{4}-280$, resulting in its decreased photodegradation ability.

\subsection{Photodegradation mechanism of SMZ}

To elucidate the photodegradation mechanism of SMZ by $\beta-\mathrm{ZnMoO}_{4}$ and the $\beta-\mathrm{ZnMoO}_{4} / \mathrm{g}-\mathrm{C}_{3} \mathrm{~N}_{4}$ composites, photocatalytic experiments were carried out in the presence of different radical scavengers (Fig. 8). First, TBA, a widely used $\bullet \mathrm{OH}$ scavenger, was added to investigate whether it affected the degradation of SMZ. For both $\beta-\mathrm{ZnMoO}_{4}-180$ and $\beta-\mathrm{ZnMoO}_{4}-180 / \mathrm{g}-\mathrm{C}_{3} \mathrm{~N}_{4}$ samples, TBA caused only a slight decrease of photocatalytic ability. When a scavenger for ${ }^{1} \mathrm{O}_{2}$ $\left(\mathrm{NaN}_{3}\right)$ was added to the photocatalytic experiments, similar results were obtained. These results indicated that $\bullet \mathrm{OH}$ and ${ }^{1} \mathrm{O}_{2}$ were not the primary oxidative species in the photodegradation of SMZ. By contrast, the addition of TEOA or BQ markedly retarded SMZ photodegradation. TEOA and BQ are scavengers for $\mathrm{h}^{+}$and $\bullet \mathrm{O}_{2}{ }^{-}$, respectively, indicating that the photodegradation mechanism of the samples was mainly associated with $\mathrm{h}^{+}$ and $\bullet \mathrm{O}_{2}^{-}$.

UV-vis DRS of $\beta-\mathrm{ZnMoO}_{4}$ are presented in Fig. 9(a). The absorption edge of $\mathrm{ZnMoO}_{4}$ was in the visible region, corresponding to band gaps $\left(\mathrm{E}_{\mathrm{g}}\right)$ of $3.078 \mathrm{eV}$ for $\beta-\mathrm{ZnMoO}_{4}-180$ and $3.038 \mathrm{eV}$ for $\beta-\mathrm{ZnMoO}_{4}-280$. The conduction band (CB) of the $\beta-\mathrm{ZnMoO}_{4}$ samples was determined by Mott-Schottky analysis. As shown in Fig. 9(b), the flat-band (FB) potential of $\beta-\mathrm{ZnMoO}_{4}-180$ was estimated to be $-1.08 \mathrm{~V}$ vs. SCE, and the positive slope of this linear plot suggests the n-type character of this sample. It has been reported that the CB potentials of n-type semiconductors are $0.1-0.2 \mathrm{~V}$ more negative than their FB potential [41]. Assuming that the CB edge is $0.1 \mathrm{~V}$ more negative than the $\mathrm{FB}$ potential, the estimated $\mathrm{CB}$ edge for $\beta-\mathrm{ZnMoO}_{4}-180$ is $-1.18 \mathrm{~V}$ vs. SCE $(-0.94 \mathrm{~V}$ vs. normal hydrogen

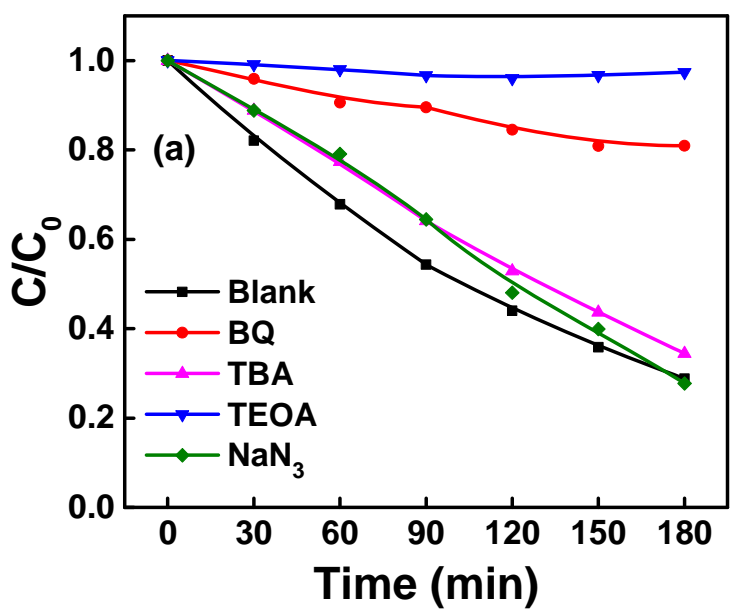

electrode (NHE)), and the estimated valence band (VB) is 1.90 $\mathrm{V}$ vs. SCE (2.14 V vs. NHE). Likewise, the estimated CB edge for $\beta-\mathrm{ZnMoO}_{4}-280$ is $-1.27 \mathrm{~V}$ vs. SCE $(-1.03 \mathrm{~V}$ vs. NHE), and its VB is $1.77 \mathrm{~V}$ vs. SCE (2.01 V vs. NHE). UV-vis DRS and Mott-Schottky plots for g- $\mathrm{C}_{3} \mathrm{~N}_{4}$ are shown in Fig. S3 and S4 in the SI; its determined $\mathrm{CB}$ and $\mathrm{VB}$ positions are -1.04 and $1.77 \mathrm{~V}$ vs. NHE, respectively. The band structures of $\beta-\mathrm{ZnMoO}_{4}$ and g- $\mathrm{C}_{3} \mathrm{~N}_{4}$ are summarized in Fig. 9(c).

The EIS analysis of $\beta-\mathrm{ZnMoO}_{4}-180$ and $\beta-\mathrm{ZnMoO}_{4}-180 / \mathrm{g}-\mathrm{C}_{3} \mathrm{~N}_{4}-3 \%$ was performed to investigate the effect of g- $\mathrm{C}_{3} \mathrm{~N}_{4}$ modification on electrode behavior. Generally, a smaller arc size in a Nyquist plot indicates lower charge transfer resistance on an electrode surface $[15,42]$. The arc radius of the Nyquist plot of $\beta-\mathrm{ZnMoO}_{4}-180 / \mathrm{g}-\mathrm{C}_{3} \mathrm{~N}_{4}-3 \%$ was smaller than that of the $\beta-\mathrm{ZnMoO}_{4}-180$ sample under illumination (Fig. S5 in the SI), suggesting that the separation and transfer efficiency of photoinduced electron-hole pairs was increased through an interfacial interaction between $\beta-\mathrm{ZnMoO}_{4}-180$ and g- $\mathrm{C}_{3} \mathrm{~N}_{4}$ particles in the composite. The proposed photocatalytic degradation process of the $\beta-\mathrm{ZnMoO}_{4} / \mathrm{g}-\mathrm{C}_{3} \mathrm{~N}_{4}$ composite is illustrated in Fig. 9 (c). The difference of chemical potential between the two semiconductor units results in band bending at the heterogeneous interface in the composite. This band bending induces a built-in electric field, which can drive the migration of photogenerated electrons and holes in opposite directions. Under illumination, photogenerated holes would form when electrons were excited from the VB to the $\mathrm{CB}$ of both $\beta-\mathrm{ZnMoO}_{4}$ and g- $\mathrm{C}_{3} \mathrm{~N}_{4}$. The photogenerated electrons in g- $\mathrm{C}_{3} \mathrm{~N}_{4}$ could easily migrate to the $\beta-\mathrm{ZnMoO}_{4}$ surface. The $\mathrm{CB}$ potential of $\beta-\mathrm{ZnMoO}{ }_{4}$ is more negative than the redox potential of the $\mathrm{O}_{2} / \cdot \mathrm{O}_{2}{ }^{-}$couple $(-0.33 \mathrm{eV}$ vs. $\mathrm{NHE})$, which can produce $\bullet \mathrm{O}_{2}{ }^{-}$radicals from dissolved $\mathrm{O}_{2}$. At the same time, the holes generated in the VB of $\beta-\mathrm{ZnMoO}_{4}$ could migrate to $\mathrm{g}-\mathrm{C}_{3} \mathrm{~N}_{4}$. However, the VB potential of $\mathrm{g}_{-} \mathrm{C}_{3} \mathrm{~N}_{4}$ is more negative than the redox potential of the $\cdot \mathrm{OH} / \mathrm{OH}^{-}$couple (1.99 eV vs. NHE), thus it cannot lead to the production of $\bullet \mathrm{OH}$ from the holes [13], which was also demonstrated in the photocatalytic experiments with radical scavengers (Fig. 8(b)). Therefore, the heterogeneous interface in the $\beta-\mathrm{ZnMoO}_{4} / \mathrm{g}-\mathrm{C}_{3} \mathrm{~N}_{4}$ composite markedly promoted the separa-

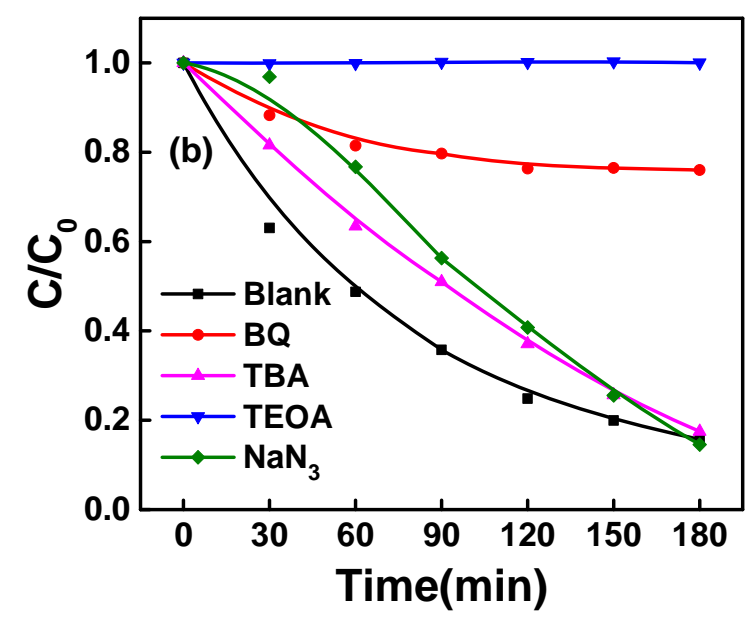

Fig. 8. Inhibition effect of different radical scavengers on the photodegradation of SMZ by $\beta-\mathrm{ZnMoO}_{4}-180$ (a) and $\beta-\mathrm{ZnMoO}-180 / \mathrm{g}-\mathrm{C}_{3} \mathrm{~N}_{4}-2 \%$ (b). 

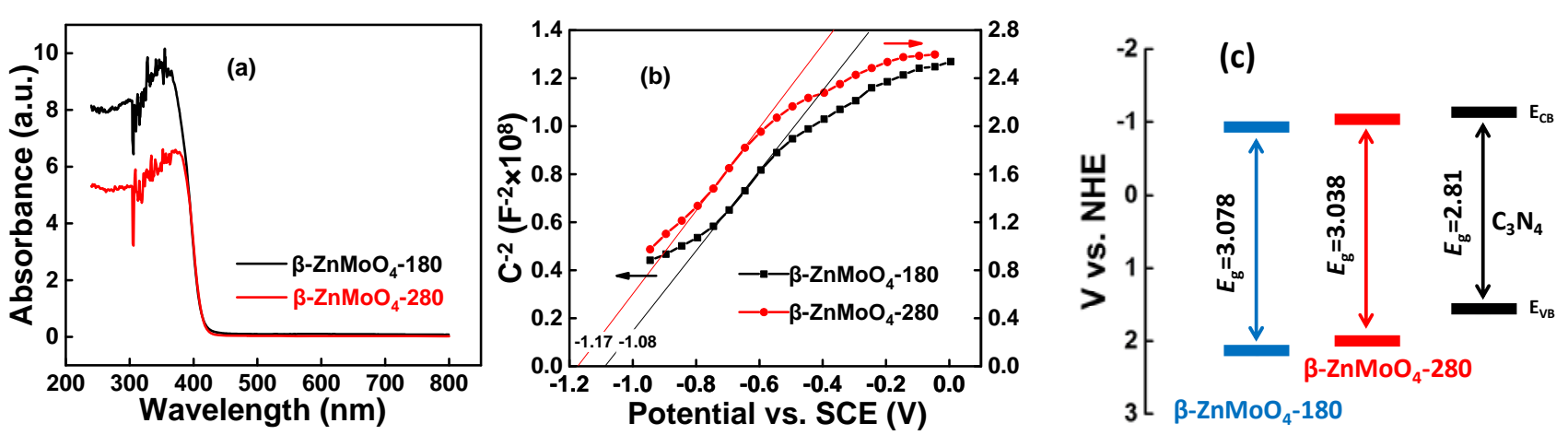

Fig. 9. UV-vis diffuse reflectance spectra of $\beta-\mathrm{ZnMoO}_{4}$ (a); Mott-Schottky plots for $\beta-\mathrm{ZnMoO}_{4}$ (b); Energy levels of the $\beta-\mathrm{ZnMoO}_{4}$ and g-C $\mathrm{C}_{4}$ samples (c).

tion of photogenerated electron-hole pairs, thereby improving its SMZ photodegradation efficiency. For the $\beta-\mathrm{ZnMoO}_{4}-180 / \mathrm{g}-\mathrm{C}_{3} \mathrm{~N}_{4}$ samples, the in situ hydrothermal synthesis ensured favorable bonding between the g- $\mathrm{C}_{3} \mathrm{~N}_{4}$ particles and $\beta-\mathrm{ZnMoO}_{4}-180$ sheets. As a result, the highest degradation efficiency of SMZ was observed for the composite with 3\% g- $\mathrm{C}_{3} \mathrm{~N}_{4}$ (Fig. 6(c)). By contrast, for the samples prepared by the ultrasonic method, the bonding of the $\mathrm{g}-\mathrm{C}_{3} \mathrm{~N}_{4}$ particles on the surface of the $\beta-\mathrm{ZnMoO}_{4}-180$ sheets may be not as strong as that of the samples prepared by the in situ hydrothermal method. Therefore, a larger $\mathrm{g}-\mathrm{C}_{3} \mathrm{~N}_{4}$ content of $8 \%$ was needed to achieve an evident enhancement effect of $\mathrm{g}-\mathrm{C}_{3} \mathrm{~N}_{4}$ on SMZ degradation for composites prepared by the ultrasonic method.

\subsection{Degradation pathway of SMZ}

The photodegradation of SMZ and the formation of several intermediates were studied by LC-MS analysis. Fig. 10(a) shows the total ion chromatogram obtained after $60 \mathrm{~min}$ of photodegradation by $\beta-\mathrm{ZnMoO}_{4}-180 / \mathrm{g}-\mathrm{C}_{3} \mathrm{~N}_{4}$. In this study, a molecular ion peak at a mass-to-charge $(\mathrm{m} / \mathrm{z})$ of 279 was observed at $5.265 \mathrm{~min}$, which was attributed to SMZ. Seven products with different $m / z$ ratios, as indicated by peak A to $\mathrm{H}$ in Fig. 10a, were identified and are labeled in Table S1. Fig. 10(b) reveals that the TOC content of the solution decreased by $20 \%$ after $9 \mathrm{~h}$ of photocatalytic degradation, which indicated that SMZ was mineralized; that is, inorganic ions such as $\mathrm{SO}_{4}{ }^{2-}$ and $\mathrm{NO}_{3}{ }^{-}$may be generated as the final degradation products. The LC-MS analysis results confirmed that $\mathrm{SO}_{4}{ }^{2-}$ and $\mathrm{NO}_{3}{ }^{-}$were present in the solution with concentrations of 1.575 and $0.175 \mathrm{mg} / \mathrm{L}$, respectively, after $6 \mathrm{~h}$ of photocatalytic degradation.

A number of studies have determined that degradation of sulfonamides occurs through cleavage at various positions [43], as shown in Fig. 11. In this study, compound $d(m / z=215)$ was observed, which is most likely a product of $-\mathrm{SO}_{2}$ - extrusion (cleavage at the $\gamma$ and $\delta$ positions in Fig. 11). Several possible pathways for the formation of extrusion products with $m / z=$ 215 have been proposed $[33,44,45]$. Subsequently, the $h^{+}$and $\cdot \mathrm{O}_{2}{ }^{-}$attacked the carbon-nitrogen bond between the benzene and pyrimidine rings in compound $d$, resulting in two products, $a$ and $c$ (Fig. 11), as also identified by Guo et al. [44]. The product with $m / z=265$ identified at 1.245 min (compound $b$ ) and that with $m / z=239$ identified at $2.326 \mathrm{~min}$ (compound $e$ ) correspond to products of amino group extrusion (cleavage at position $\beta$ ) or methyl group extrusion. Another pathway involves the benzene and pyrimidine rings of SMZ being attacked by reactive oxygen species to cause hydroxylation, which has been reported in other studies [33]. Moreover, the continuous
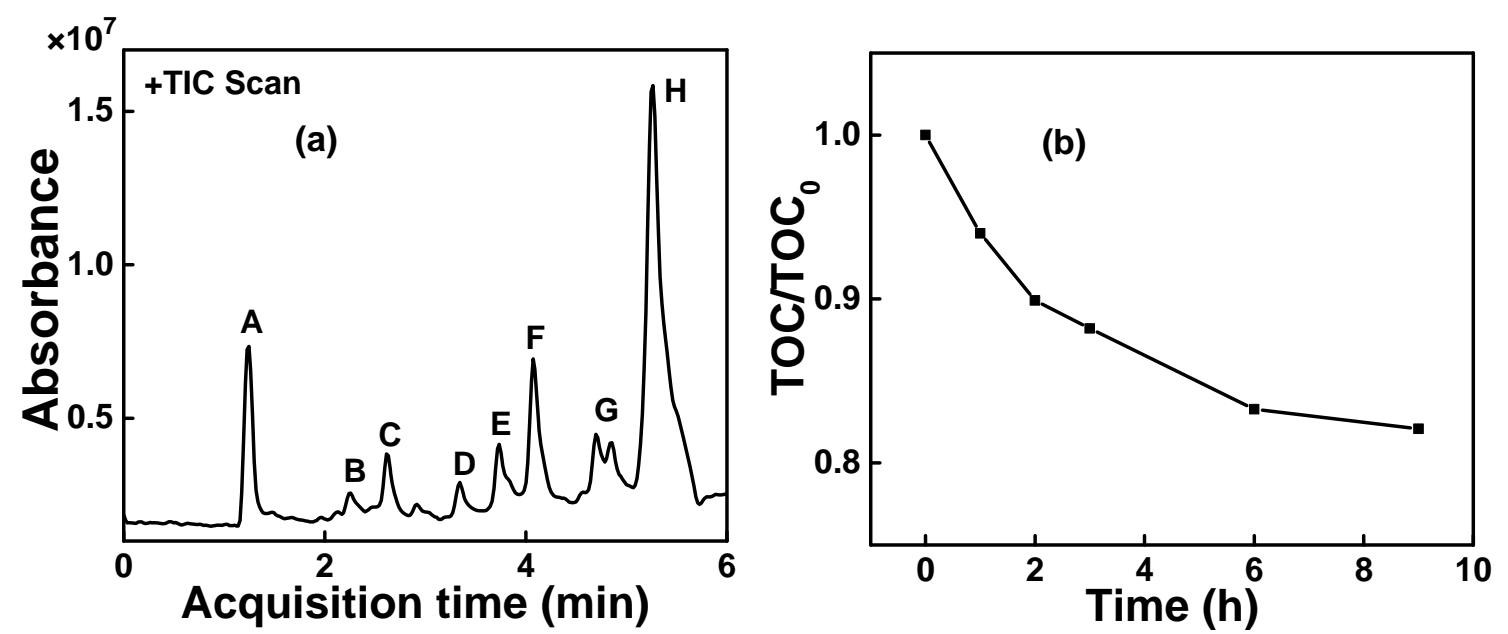

Fig. 10. TIC of SMZ after photodegradation for $1.5 \mathrm{~h}(\mathrm{a})$. Decrease of TOC in the solution during SMZ photodegradation (b). The initial concentration of SMZ was $10 \mathrm{mg} / \mathrm{L} . \beta-\mathrm{ZnMoO}_{4}-180 / \mathrm{g}-\mathrm{C}_{3} \mathrm{~N}_{4}-3 \%$ was used as the catalyst. 
<smiles>Cc1cc(C)nc(NS(=O)(=O)c2ccc(N)c(O)c2)n1</smiles>

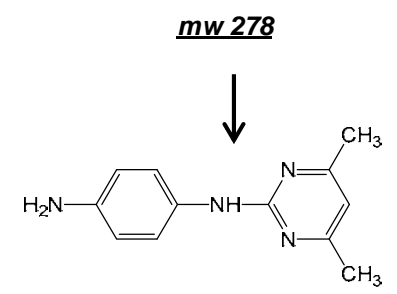<smiles>Cc1ccnc(NS(=O)(=O)c2ccc(N)cc2)n1</smiles><smiles>CCC</smiles><smiles>Cc1nc(NS(=O)(=O)c2ccc(N)cc2)nc(C)c1O</smiles>

$\underline{d ~ m w 214}$<smiles>Nc1ccc(O)cc1</smiles>

a $\operatorname{mw} 109$

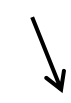<smiles>Cc1cc(C)nc(N)n1</smiles>

c mw 123<smiles>Cc1cc(C)nc(NS(=O)(=O)c2ccccc2)n1</smiles>

b mw 264/263

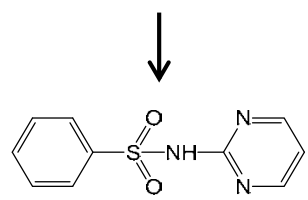

$\stackrel{\text { e mw 235 }}{\downarrow}$
$\mathrm{CO}_{2}, \mathrm{H}_{2} \mathrm{O}, \mathrm{NO}_{3}^{-}$,
$\mathrm{NH}_{4}^{+}, \mathrm{SO}_{4}{ }^{2-}$ etc.<smiles>Cc1ccnc(NS(=O)(=O)c2ccc(N)c(O)c2)n1</smiles>

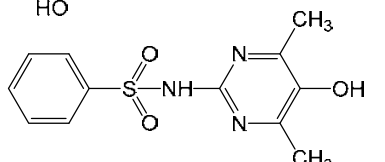<smiles>Cc1cc(C)nc(NS(=O)(=O)c2cccc(O)c2)n1</smiles>

$\underline{f m w 280 / 279}$

Fig. 11. Proposed pathways for $S M Z$ photodegradation by the $\beta-\mathrm{ZnMoO}_{4}-180 / \mathrm{g}-\mathrm{C}_{3} \mathrm{~N}_{4}-3 \%$ composite.

attack of the hydroxylated SMZ by reactive species results in the loss of an amino or methyl group, corresponding to the product with $m / z=283$ (compound $f$ ). Intermediate $f$ might also be formed by the hydroxylation of compound $b$ with $\bullet \mathrm{OH}$. Subsequently, these intermediates may decompose into smaller molecules, ending up as environmentally benign compounds, such as $\mathrm{SO}_{4}{ }^{2-}$ and $\mathrm{NO}_{3}{ }^{-}$, which were detected by ion chromatography.

\section{Conclusions}

In summary, $\beta-\mathrm{ZnMoO}_{4}$ catalysts with different morphologies were synthesized via the hydrothermal method. Both the in situ hydrothermal and ultrasonic methods were used to fabricate g- $\mathrm{C}_{3} \mathrm{~N}_{4}$-modified $\beta-\mathrm{ZnMoO}_{4}$ composites. Our results indicated that $\beta-\mathrm{ZnMoO}_{4}$ microparticles with a unique microstructure were good platforms for the introduction of visible-light-responsive g- $\mathrm{C}_{3} \mathrm{~N}_{4}$. The pristine $\beta-\mathrm{ZnMoO}_{4}-280$ sample obtained showed higher photocatalytic activity than $\beta-\mathrm{ZnMoO}_{4}-180$. In the case of $\beta-\mathrm{ZnMoO}_{4}-180 / \mathrm{g}-\mathrm{C}_{3} \mathrm{~N}_{4}$ composites, the surface-modified samples all showed enhanced photocatalytic activity relative to that of the pristine $\beta-\mathrm{ZnMoO}_{4}-180$ sample. By contrast, the structural incorporation of $\mathrm{g}-\mathrm{C}_{3} \mathrm{~N}_{4}$ into $\beta$ - $\mathrm{ZnMoO}_{4}$ crystals prepared at $280^{\circ} \mathrm{C}$ lowered their crystallinity, thereby deteriorating the performance of these composite catalysts. Study of the photocatalytic mechanism of the compo- sites revealed that $\mathrm{h}^{+}$and $\bullet \mathrm{O}_{2}{ }^{-}$were the dominant oxidative species in the SMZ photodegradation process. The enhanced photocatalytic performance of the composites was attributed to the higher separation efficiency of the photogenerated electron-hole pairs at their heterogeneous interfaces. Compared with the ultrasonic method, the hydrothermal synthesis at 180 ${ }^{\circ} \mathrm{C}$ resulted in a more favorable interaction between $\mathrm{g}-\mathrm{C}_{3} \mathrm{~N}_{4}$ and $\beta-\mathrm{ZnMoO}_{4}$, and the optimal $\mathrm{g}-\mathrm{C}_{3} \mathrm{~N}_{4}$ content was $3 \%$. SMZ was effectively photodegraded by the $\beta-\mathrm{ZnMoO}_{4} / \mathrm{g}-\mathrm{C}_{3} \mathrm{~N}_{4}$ composites, and the degradation mechanism involved the extrusion of $-\mathrm{SO}_{2}$ - and amino groups. This work highlights the importance of selecting an appropriate method to prepare composite photocatalytic materials based on $\mathrm{g}-\mathrm{C}_{3} \mathrm{~N}_{4}$. The abundant molybdenum resources in China may be used to prepare catalytic materials for various applications in environmental and energy fields.

\section{References}

[1] L. Huang, W. Zhang, J. W. Xiang, H. H. Xu, G. L. Li, Y. H. Huang, Sci. Rep., 2016, 6, 31465.

[2] Z. Q. Zhang, H. D. Zhang, X. Y. Zhang, D. Y. Yu, Y. Ji, Q. S. Sun, Y. Wang, X. Y. Liu, J. Mater. Chem. A, 2016, 4, 18578-18584.

[3] A. V. Veresnikova, B. K. Lubsandorzhiev, I. R. Barabanov, P. Grabmayr, D. Greiner, J. Jochum, M. Knapp, C. Osswald, R. V. Poleshuk, F. Ritter, B. A. M. Shaibonov, Y. E. Vyatchin, G. Meierhofer, Nucl. Instrum. Methods in Phys. Res., Sect. A, 2009, 603, 529-531. 


\section{Graphical Abstract}

Chin. J. Catal., 2017, 38: 2009-2020 doi: 10.1016/S1872-2067(17)62935-8

Photocatalytic degradation of sulfamethazine by graphitic carbon nitride-modified zinc molybdate: Effects of synthesis method on performance, degradation kinetics, and mechanism

Jing Zhang, Xuhui Mao *, Wei Xiao, Yanfeng Zhuang*

Wuhan University

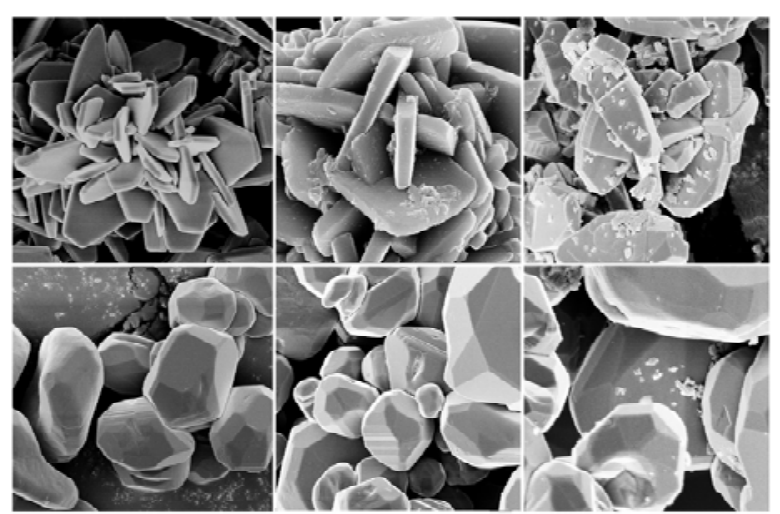

(in situ hydrothermal) (ultrasonication)

$\beta-\mathrm{ZnMoO}_{4} \quad \beta-\mathrm{ZnMoO}_{4} / \mathrm{C}_{3} \mathrm{~N}_{4}$

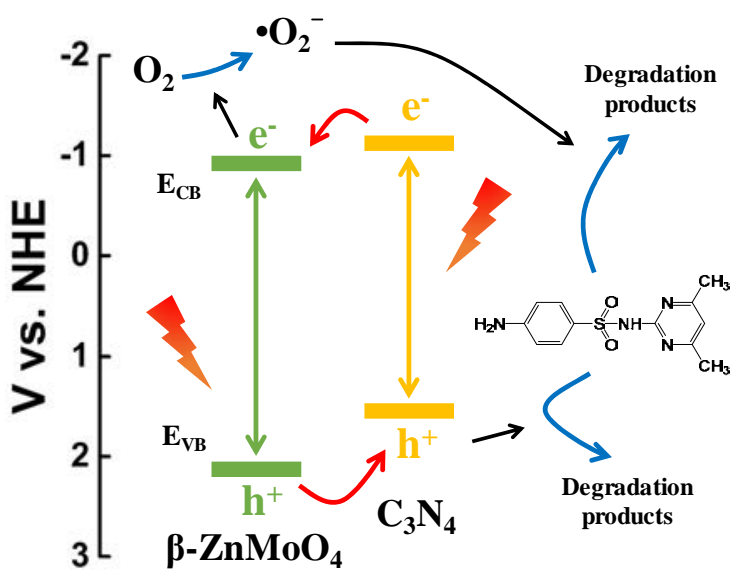

$\beta-\mathrm{ZnMoO}_{4} / \mathrm{C}_{3} \mathrm{~N}_{4}$ composites were successfully synthesized via different methods. Surface modification of $\beta$ - $\mathrm{ZnMoO} \mathrm{O}_{4}$ with $\mathrm{C}_{3} \mathrm{~N}_{4}$ resulted in enhanced photocatalytic activity, and this observation is attributed to the higher separation efficiency of photogenerated electron-hole pairs.

[4] V. B. Mikhailik, H. Kraus, V. Kapustyanyk, M. Panasyuk, Y. Prots, V. Tsybulskyi, L. Vasylechko, J. Phys., 2008, 20, 365219.

[5] Y. Liang, P. Liu, H. B. Li, G. W. Yang, Cryst. Growth Des., 2012, 12, 4487-4493.

[6] M. Grzywa, W. Łasocha, W. Surga, J. Solid State Chemistry, 2007, 180, 1590-1594.

[7] G. K. Zhang, S. J. Yu, Y. R. Yang, W. Jiang, S. M. Zhang, B. B. Huang, J. Cryst. Growth, 2010, 312, 1866-1874.

[8] Y. R. Jiang, W. W. Lee, K. T. Chen, M. C. Wang, K. H. Chang, C. C. Chen, J. Taiwan Inst. Chem. Eng., 2014, 45, 207-218.

[9] Y. Keereeta, T. Thongtem, S. Thongtem, Superlattices Microstruct., 2014, 69, 253-264.

[10] M. Ramezani, S. M. Hosseinpour-Mashkani, A. Sobhani-Nasab, H. Ghasemi Estarki, J. Mater. Sci., 2015, 26, 7588-7594.

[11] Q. D. Zeng, J. M. Liu, K. Z. Qin, H. R. Fan, S. X. Chu, Y. B. Wang, L. L. Zhou, Int. Geol. Rev., 2013, 55, 1311-1358.

[12] S. W. Cao, J. X. Low, J. G. Yu, M. Jaroniec, Adv. Mater, 2015, 27, 2150-2176.

[13] S. W. Zhang, J. X. Li, M. Y. Zeng, G. X. Zhao, J. Z. Xu, W. P. Hu, X. K. Wang, ACS Appl. Mater. Interfaces, 2013, 5, 12735-12743.

[14] S. W. Liu, F. Chen, S. T. Li, X. X. Peng, Y. Xiong, Appl. Catal., B, 2017, 211, 1-10.

[15] S. L. Ma, S. H. Zhan, Y. N. Jia, Q. Shi, Q. X. Zhou, Appl. Catal., B, 2016, $186,77-87$.

[16] M. X. Ji, J. Di, Y. P. Ge, J. X. Xia, H. M. Li, Appl. Surf. Sci., 2017, 413, 372-380.

[17] Y. J. Wang, Z. X. Wang, S. Muhammad, J. He, CrystEngComm., 2012, 14, 5065-5070.

[18] G. C. Bi, J. Q. Wen, X. Li, W. Liu, J. Xie, Y. P. Fang, W. W. Zhang, RSC Adv., 2016, 6, 31497-31506.
[19] G. Z. Liao, S. Chen, X. Quan, H. T. Yu, H. M. Zhao, J. Mater. Chem., 2012, 22, 2721-2726.

[20] D. L. Jiang, L. L. Chen, J. J. Zhu, M. Chen, W. D. Shi, J. M. Xie, J. Chem. Soc., Dalton Trans., 2013, 42, 15726-15734.

[21] J. Xu, G. X. Wang, J. J. Fan, B. S. Liu, S. M. Cao, J. G. Yu, J. Power Sources, 2015, 274, 77-84.

[22] L. Pi, R. Jiang, W. C. Zhou, H. Zhu, W. Xiao, D. H. Wang, X. H. Mao, Appl. Surf. Sci., 2015, 358, 231-239.

[23] Y. Z. Hong, C. S. Li, G. Y. Zhang, Y. D. Meng, B. X. Yin, Y. Zhao, W. D. Shi, Chem. Eng. J., 2016, 299, 74-84.

[24] X. J. Bai, L. Wang, Y. J. Wang, W. Q. Yao, Y. F. Zhu, Appl. Catal., B, 2014, 152, 262-270.

[25] M. S. Akple, J. X. Low, S. Wageh, A. A. Al-Ghamdi, J. G. Yu, J. Zhang, Appl. Surf. Sci., 2015, 358, 196-203.

[26] L. F. Cui, X. Ding, Y. G. Wang, H. C. Shi, L. H. Huang, Y. H. Zuo, S. F. Kang, Appl. Surf. Sci., 2017, 391, 202-210.

[27] Q. Hao, S. M. Hao, X. X. Niu, X. Li, D. M. Chen, H. Ding, Chin. J. Catal,, 2017, 38, 278-286.

[28] J. Li, M. Zhang, Q. Y. Li, J. J. Yang, Appl. Surf. Sci., 2017, 391, 184-193.

[29] J. G. Yu, S. H. Wang, B. Cheng, Z. Lin, F. Huang, Catal. Sci. Technol,, 2013, 3, 1782-1789.

[30] D. D. Tang, G. K. Zhang, Appl. Surf. Sci., 2017, 391, 415-422.

[31] C. Han, Y. D. Wang, Y. P. Lei, B. Wang, N. Wu, Q. Shi, Q. Li, Nano Res., 2015, 8, 1199-1209.

[32] S. Fukahori, T. Fujiwara, J. Environ. Manage., 2015, 157, 103-110.

[33] S. Rafqah, Z. S. Seddigi, S. A. Ahmed, E. Danish, M. Sarakha, J. Mass Spectrom, 2015, 50, 298-307.

[34] X. F. Li, J. Zhang, L. H. Shen, Y. M. Ma, W. W. Lei, Q. L. Cui, G. T. Zou, Appl. Phys. A, 2008, 94, 387-392. 
[35] S. C. Yan, Z. S. Li, Z. G. Zou, Langmuir, 2009, 25, 10397-10401.

[36] D. C. Agarwal, D. K. Avasthi, S. Varma, F. Kremer, M. C. Ridgway, D. Kabiraj, J. Appl. Phys., 2014, 115, 163506.

[37] M. Cerna, C. Guillard, E. Puzenat, M. Vesely, P. Dzik, Int. J. Chem. Environ. Eng., 2011, 2, 255-260.

[38] P. Y. Dong, Y. H. Wang, B. Liu, L. N. Guo, Y. J. Huang, S. Yin, Appl. Surf. Sci., 2012, 258, 7052-7058.

[39] T. Z. Liu, Y. Y. Li, H. Zhang, M. Wang, X. Y. Fei, S. W. Duo, Y. Chen, J. Pan, W. Wang, Appl. Surf. Sci., 2015, 357, 516-529.

[40] L. S. Cavalcante, J. C. Sczancoski, M. Siu Li, E. Longo, J. A. Varela,
Colloids Surf., A, 2012, 396, 346-351.

[41] S. Emin, M. de Respinis, T. Mavrič, B. Dam, M. Valant, W. A. Smith, Appl. Catal., A, 2016, 523, 130-138.

[42] B. C. Zhu, P. F. Xia, Y. Li, W. K. Ho, J. G. Yu, Appl. Surf. Sci., 2017, 391, 175-183.

[43] Y. K. Liu, J. L. Wang, J. Hazard. Mater., 2013, 250-251, 99-105.

[44] C. S. Guo, J. Xu, S. F. Wang, Y. Zhang, Y. He, X. F. Li, Catal. Sci. Technol., 2013, 3, 1603-1611.

[45] M. Perisa, S. Babic, I. Skoric, T. Fromel, T. C. P. Knepper, Environ. Sci. Pollut. Res., 2013, 20, 8934-8946.

\title{
g- $\mathrm{C}_{3} \mathrm{~N}_{4}$ 修饰 $\beta-Z n \mathrm{MoO}_{4}$ 光催化降解磺胺二甲嘧啶: 合成方法的影响、 降解动力学及机理
}

\author{
张 婧 ${ }^{\mathrm{a}}$, 毛旭辉, ${ }^{\mathrm{a},}$, 肖 巍, 庄艳峰 ${ }^{\mathrm{b}, \#}$ \\ $\mathrm{a}$ 武汉大学资源与环境科学学院, 湖北省资源与能源可持续利用技术示范型国际科技合作基地, 湖北武汉430079

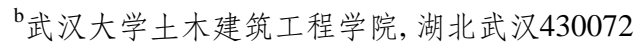

\begin{abstract}
摘要: 在过去几十年中, 钼酸盐在功能材料领域的应用备受关注. 例如, 半导体材料二价金属钿酸盐 $\mathrm{MMoO}_{4}(\mathrm{M}=\mathrm{Ca}, \mathrm{Mg}$, $\mathrm{Zn}$ )在发光、催化、电容器、闪㷧探测器等方面已有良好的应用. 研究表明, 钼酸锌在紫外或可见光照射下能够有效降解甲 基橙、维多利亚蓝、苯酚等污染物. 中国拥有丰富的钿资源, 目前钿主要用于生产高强度钢. 制备钿基高效除污除材料可 作为钼资源的另一种高附加值利用模式. 氮化碳 $\left(\mathrm{g}-\mathrm{C}_{3} \mathrm{~N}_{4}\right)$ 作为一种低成本的光活性改性剂, 可提高半导体材料的光催化性 能. 迄今为止, 基于氮化碳复合材料的制备方法包括: 原位水热合成、超声波复合、一步升温合成和沉淀法等. 然而, 很少 讨论合成方法对复合材料性能的影响. 本文以 $\beta-\mathrm{ZnMoO}_{4}$ 为主体材料, $\mathrm{g}-\mathrm{C}_{3} \mathrm{~N}_{4}$ 为修饰材料, 首次制备了两者复合的新型光催 化剂. 采用不同的方法和条件制备了 $\beta-\mathrm{ZnMoO}_{4}$ 和 $\beta-\mathrm{ZnMoO}_{4} / \mathrm{C}_{3} \mathrm{~N}_{4}$ 复合材料, 探讨了合成方法对复合材料光催化性能的影 响, 并进一步研究了材料光催化降解磺胺二甲嘧啶的动力学和降解途径.

以钿酸钠和硝酸锌为原料, 在不同温度和时间条件下, 采用水热法合成得到了两种不同形貌的 $\beta-\mathrm{ZnMoO}{ }_{4}$ 材料. 光催化 降解实验结果显示, 水热合成条件对催化剂的光催化活性影响很大, $280^{\circ} \mathrm{C}$ 水热条件下维持 $24 \mathrm{~h}$, 得到表面光滑的不规则微 米颗粒 $(\beta-\mathrm{ZnMoO}-280)$, 其光催化活性高于 $180^{\circ} \mathrm{C}$ 条件下获得的片状形貌的锄酸锌材料 $\left(\beta-\mathrm{ZnMoO}_{4}-180\right) . \quad \beta-\mathrm{ZnMoO}_{4} / \mathrm{C}_{3} \mathrm{~N}_{4}$ 复合材料通过原位水热法和超声法合成, 结果显示, 原位水热合成条件下获得的 $\beta-\mathrm{ZnMoO}_{4}-180 / \mathrm{C}_{3} \mathrm{~N}_{4}$ 光催化剂对磺胺二甲 嘧啶表现出显著增强的降解能力. 相比之下, 在 $280^{\circ} \mathrm{C}$ 水热条件下, $\mathrm{C}_{3} \mathrm{~N}_{4}$ 颗粒发生逐步分解, 且反应开始时 $\mathrm{C}_{3} \mathrm{~N}_{4}$ 颗粒会扰乱 $\beta-\mathrm{ZnMoO}_{4}-280$ 晶体生长的连续性, 使复合材料性能下降. 对于超声法合成的 $\beta-\mathrm{ZnMoO}_{4} / \mathrm{C}_{3} \mathrm{~N}_{4}$ 材料, 两种 $\beta-\mathrm{ZnMoO}_{4} / \mathrm{C}_{3} \mathrm{~N}_{4}$ 复 合材料的光催化活性均提高, 但提高程度不及水热法 $180^{\circ} \mathrm{C}$ 条件下制备的材料. 结果表明, 对于光催化复合材料的制备, 要 选择适当的合成方法, 才能得到高性能复合光催化材料, 本文采用 $180^{\circ} \mathrm{C}$ 的水热合成条件, 添加 $3 \% \mathrm{~g}-\mathrm{C}_{3} \mathrm{~N}_{4}$, 可得到性能最佳 的 $\beta-\mathrm{ZnMoO}_{4}-180 / \mathrm{C}_{3} \mathrm{~N}_{4}$ 复合光催化剂.

添加自由基抑制剂的光催化降解实验结果表明, 超氧负离子 $\left(\cdot \mathrm{O}_{2}{ }^{-}\right)$和空穴 $\left(\mathrm{h}^{+}\right)$在降解中起主导作用. $\beta-\mathrm{ZnMoO}_{4} / \mathrm{C}_{3} \mathrm{~N}_{4}$ 复 合材料光催化活性的增强归因于 $\mathrm{C}_{3} \mathrm{~N}_{4}$ 与 $\beta-\mathrm{ZnMoO}_{4}$ 之间形成异质结, 该异质结提高了光生电子-空穴对的分离效率. 通过液 相-质谱联用手段, 测定了磺胺二甲嘧啶降解的中间产物, 结果表明, 污染物的光催化降解途径主要包括脱氨基和脱甲基过 程.
\end{abstract}

关键词: 钿酸锌; 石墨相氮化碳; 光催化; 磺胺二甲嘧啶; 水处理

收稿日期: 2017-09-11. 接受日期: 2017-10-19. 出版日期: 2017-12-05.

*通讯联系人. 电话: (027)68775799; 电子信箱: clab@whu.edu.cn

\#通讯联系人. 电话: (027)68775799; 电子信箱: zhuang0848@sina.com

基金来源：国家自然科学基金(51778505); 湖北省技术创新重大专项(2016ACA162); 湖北省自然科学基金创新团队项目 (2015CFA017).

本文的英文电子版由Elsevier出版社在ScienceDirect上出版(http://www.sciencedirect.com/science/journal/18722067). 